\title{
Impacts of enhanced weathering on biomass production for negative emission technologies and soil hydrology
}

\author{
Wagner de Oliveira Garcia ${ }^{1}$, Thorben Amann ${ }^{1}$, Jens Hartmann ${ }^{1}$, Kristine Karstens ${ }^{2}$, Alexander Popp ${ }^{2}$, \\ Lena R. Boysen ${ }^{3}$, Pete Smith ${ }^{4}$, and Daniel Goll ${ }^{5,6}$ \\ ${ }^{1}$ Institute of Geology, Center for Earth System Research and Sustainability, University of Hamburg, Hamburg, Germany \\ ${ }^{2}$ Potsdam Institute for Climate Impact Research (PIK), Potsdam, Germany \\ ${ }^{3}$ Land in the Earth System (LES), Max Planck Institute for Meteorology, Hamburg, Germany \\ ${ }^{4}$ Institute of Biological and Environmental Sciences, School of Biological Sciences, University of Aberdeen, Aberdeen, UK \\ ${ }^{5}$ Laboratoire des Sciences du Climat et de 1'Environnement, CEA, CNRS, UVSQ, 91190 Gif-sur-Yvette, France \\ ${ }^{6}$ Institute of Geography, University of Augsburg, Augsburg, Germany
}

Correspondence: Wagner de Oliveira Garcia (wagner.o.garcia@gmail.com)

Received: 24 September 2019 - Discussion started: 9 October 2019

Revised: 21 February 2020 - Accepted: 10 March 2020 - Published: 17 April 2020

\begin{abstract}
Limiting global mean temperature changes to well below $2{ }^{\circ} \mathrm{C}$ likely requires a rapid and large-scale deployment of negative emission technologies (NETs). Assessments so far have shown a high potential of biomass-based terrestrial NETs, but only a few assessments have included effects of the commonly found nutrient-deficient soils on biomass production. Here, we investigate the deployment of enhanced weathering (EW) to supply nutrients to areas of afforestation-reforestation and naturally growing forests (AR) and bioenergy grasses (BG) that are deficient in phosphorus $(\mathrm{P})$, besides the impacts on soil hydrology. Using stoichiometric ratios and biomass estimates from two established vegetation models, we calculated the nutrient demand of $\mathrm{AR}$ and $\mathrm{BG}$. Insufficient geogenic $\mathrm{P}$ supply limits $\mathrm{C}$ storage in biomass. For a mean $\mathrm{P}$ demand by $\mathrm{AR}$ and a lowgeogenic-P-supply scenario, AR would sequester $119 \mathrm{GtC}$ in biomass; for a high-geogenic-P-supply and low-AR-Pdemand scenario, $187 \mathrm{Gt} C$ would be sequestered in biomass; and for a low geogenic $\mathrm{P}$ supply and high AR P demand, only $92 \mathrm{GtC}$ would be accumulated by biomass. An average amount of $\sim 150 \mathrm{Gt}$ basalt powder applied for EW would be needed to close global $\mathrm{P}$ gaps and completely sequester projected amounts of $190 \mathrm{GtC}$ during the years 2006-2099 for the mean AR P demand scenario (2-362 Gt basalt powder for the low-AR-P-demand and for the high-AR-P-demand scenarios would be necessary, respectively). The average potential of carbon sequestration by EW until 2099 is $\sim 12 \mathrm{GtC}$
\end{abstract}

$(\sim 0.2-\sim 27 \mathrm{GtC})$ for the specified scenarios (excluding additional carbon sequestration via alkalinity production). For $\mathrm{BG}, 8 \mathrm{~kg}$ basalt $\mathrm{m}^{-2} \mathrm{a}^{-1}$ might, on average, replenish the exported potassium $(\mathrm{K})$ and $\mathrm{P}$ by harvest. Using pedotransfer functions, we show that the impacts of basalt powder application on soil hydraulic conductivity and plant-available water, to close predicted $\mathrm{P}$ gaps, would depend on basalt and soil texture, but in general the impacts are marginal. We show that EW could potentially close the projected $\mathrm{P}$ gaps of an $\mathrm{AR}$ scenario and nutrients exported by $\mathrm{BG}$ harvest, which would decrease or replace the use of industrial fertilizers. Besides that, EW ameliorates the soil's capacity to retain nutrients and soil $\mathrm{pH}$ and replenish soil nutrient pools. Lastly, EW application could improve plant-available-water capacity depending on deployed amounts of rock powder - adding a new dimension to the coupling of land-based biomass NETs with EW.

\section{Introduction}

To limit temperature increase due to climate change to well below $2{ }^{\circ} \mathrm{C}$ compared to preindustrial levels by the end of the century, research efforts on negative emission technologies (NETs; i.e., ways to actively remove $\mathrm{CO}_{2}$ from the atmosphere) intensify. Terrestrial NETs encompass bioenergy with carbon capture and storage (BECCS); afforesta- 
tion, reforestation and naturally growing forests (AR); enhanced weathering (EW); biochar; restoration of wetlands; and soil carbon sequestration. From these land-based NET options, BECCS, AR, biochar, and EW can potentially be combined to increase atmospheric carbon dioxide removal (CDR; Smith et al., 2016; Beerling et al., 2018; Amann and Hartmann, 2019).

BECCS combines energy production from biomass and carbon capture at the power plant with subsequent storage. Sources for biomass-based energy production are crop and forestry residues (Smith, 2012; Smith et al., 2012; Tokimatsu et al., 2017), dedicated bioenergy grass (BG) plantations (Smith, 2012; Smith et al., 2012), or short-rotation woody biomass from forestry (Cornelissen et al., 2012; Smeets and Faaij, 2007). Large-scale AR, as well as bioenergy plantations, requires extensive landscape modifications for growing forests or natural regrowth of trees in deforested areas to increase terrestrial CDR (Kracher, 2017; Boysen et al., 2017a; Popp et al., 2017; Humpenöder et al., 2014) and huge quantities of irrigation water (Boysen et al., 2017b; Bonsch et al., 2016). The biomass yields of AR and agricultural bioenergy crops directly correlate with fertilizer application, which in turn could reduce CDR efficiency due to related emissions of $\mathrm{N}_{2} \mathrm{O}$ (Creutzig, 2016; Popp et al., 2011) and initiate unwanted side effects like acidification of soils (Rockström et al., 2009; Vitousek et al., 1997), streams and rivers, and lakes (Vitousek et al., 1997).

Under intensive growth scenarios, nutrient supply is a critical factor. According to Liebig's law of the minimum, supplying high amounts of nitrogen $(\mathrm{N})$ might shift growth limitation to other nutrients (von Liebig and Playfair, 1843). Some US forests are already showing changes in line with moving from an $\mathrm{N}$-limited to a phosphorus-limited (Plimited) system caused by increases in $\mathrm{N}$ atmospheric deposition (Crowley et al., 2012) along with magnesium (Mg), potassium (K), and calcium (Ca) deficiencies (Garcia et al., 2018; Jonard et al., 2012). Poor nutrient supply, related to deficient mineral nutrition, may reduce tree growth (Augusto et al., 2017). Impacts on biomass production due to poor tree nutrition has been observed in European forests (Knust et al., 2016; Jonard et al., 2015), decreasing the carbon sequestration of forest ecosystems (Oren et al., 2001) - a factor rarely included in climate models, leading to overestimated CDR potential.

Specifically, global simulations with an $\mathrm{N}$-enabled land surface model (Kracher, 2017) suggest that insufficient soil nitrogen availability for a representative concentration pathway 4.5 (RCP4.5) AR scenario (Thomson et al., 2011) could lead to a reduction in the cumulative forest carbon sequestration between the years 2006 and 2099 by $15 \%$. Goll et al. (2012) showed that carbon sequestration during the 21st century in the JSBACH land surface model was $25 \%$ lower when $\mathrm{N}$ and $\mathrm{P}$ effects were considered.

Mineral weathering is a natural and primary source of geogenic nutrients (e.g., $\mathrm{Mg}, \mathrm{Ca}, \mathrm{K}$, and P; Hopkins and Hüner,
2008; Landeweert et al., 2001; Waldbauer and Chamberlain, 2005; Singh and Schulze, 2015) and controls atmospheric $\mathrm{CO}_{2}$ concentrations over geological timescales (Walker et al., 1981; Lenton and Britton, 2006; Berner and Garrels, 1983; Waldbauer and Chamberlain, 2005; Yasunari, 2020). Chemical dissolution of silicate minerals increases alkalinity fluxes (Kempe, 1979; Gaillardet et al., 1999; Hartmann et al., 2009), and natural weathering sequestration can range from 0.1 to $0.3 \mathrm{Gt} \mathrm{Ca}^{-1}$ (Gaillardet et al., 1999; Moon et al., 2014; Hartmann et al., 2009). To sequester significant amounts of $\mathrm{CO}_{2}$ within decades, EW aims to speed up weathering processes by increasing the mineral reactive surfaces through rock comminution (Hartmann et al., 2013; Schuiling and Krijgsman, 2006; Hartmann and Kempe, 2008). Mineral-soilmicroorganism interactions (e.g., by mycorrhizal fungi; Kantola et al., 2017; Landeweert et al., 2001; Taylor et al., 2009) increase the volume of soil that plant roots can extract nutrients from (Clarkson and Hanson, 1980; Hopkins and Hüner, 2008), which might enhance the weathering activity in addition to the reaction with dissolved $\mathrm{CO}_{2}$. EW further increases soil $\mathrm{pH}$ by alkalinity fluxes and could be a long-term source of macronutrients (e.g., $\mathrm{Mg}, \mathrm{Ca}, \mathrm{K}, \mathrm{P}$, and $\mathrm{S}$ ) and micronutrients (e.g., B, Mo, $\mathrm{Cu}, \mathrm{Fe}, \mathrm{Mn}, \mathrm{Zn}$, and $\mathrm{Ni}$; Leonardos et al., 1987; Nkouathio et al., 2008; Beerling et al., 2018; Hartmann et al., 2013; Anda et al., 2015), rejuvenating the nutrient pools of soils.

$\mathrm{P}$ is a rather immobile soil nutrient, and only a small fraction of soil $\mathrm{P}$ is readily available for plant uptake, limiting plant growth in a wide range of ecosystems (Shen et al., 2011; Elser et al., 2007). P content in soils is a result of a process controlled by the interactions of parent material (primary rocks) with climate, tectonic uplift, and erosion history through geological time (Porder and Hilley, 2011). The processes of $\mathrm{P}$ transfer between biologically available and recalcitrant $\mathrm{P}$ pools influence at most $\mathrm{P}$ availability (Porder and Hilley, 2011). Orthophosphate $\left(\mathrm{H}_{2} \mathrm{PO}_{4}^{-}\right.$or $\left.\mathrm{HPO}_{4}^{2-}\right)$ is the chemical species adsorbed by plants (Shen et al., 2011), and its solubility is controlled by soil $\mathrm{pH}$, as deprotonation occurs when $\mathrm{pH}$ increases. Ideal $\mathrm{pH}$ conditions for orthophosphate availability are from 5 to 8 (Holtan et al., 1988), with soil moisture influencing soil $\mathrm{P}$ availability for different crops (He et al., 2005, 2002; Shen et al., 2011) and natural ecosystems (Goll et al., 2018).

The inclusion of soil hydraulic properties in the evaluation of EW effects is important as the soil water content has a strong influence on average crop yield. Practices that increase the plant-available water (PAW) are thought to mitigate drought effects on crops (Rossato et al., 2017). The water content of soils also seems to influence soil erosion rates and surface runoff (Bissonnais and Singer, 1992). In addition, soil water content influences soil $p \mathrm{CO}_{2}$ production, which is a relevant agent for mineral dissolution (RomeroMujalli et al., 2018).

Deploying land-based NETs would imply large changes in a local landscape nutrient and water cycle. At least $65 \%$ of 
worldwide soils $\left(6.8 \times 10^{9}\right.$ ha of land $)$ have unfavorable soil conditions for agricultural production (Fischer et al., 2001). Therefore, we assess if applications of rock mineral-based $\mathrm{P}$ sources could close eventual nutritional gaps in an environment with natural $\mathrm{N}$ supply ( $\mathrm{N}$-limited) and with $\mathrm{N}$ fertilization (N-unlimited), using a global afforestation scenario. In addition, we investigate the effects of coupling nutrientsupplying (EW) to nutrient-demanding ( $\mathrm{AR}$ and $\mathrm{BG}$ ) landbased NETs by focusing on the efficiency of different upper limits of basalt powder to supply nutrients. We hypothesize that large-scale EW deployment potentially changes soil texture. Therefore, threshold values for impacts on soil hydraulic conductivity and plant-available water will be determined.

\section{Methods}

Since phosphorus $(\mathrm{P})$ is a limiting nutrient in a wide range of ecosystems (Elser et al., 2007), we performed a P budget for an N-stock-based P demand from an AR scenario considering natural $\mathrm{N}$ supply (hereafter $\mathrm{N}$-limited) and $\mathrm{N}$ fertilization (hereafter $\mathrm{N}$-unlimited). We selected two $\mathrm{N}$ supply scenarios since the related $\mathrm{P}$ demand is proportional to biomass $\mathrm{N}$ stock, but in the main text we discuss only the N-limited AR scenario. We estimated the balanced supply of $\mathrm{Mg}, \mathrm{Ca}$, and $\mathrm{K}$ for each supplied $\mathrm{P}$ based on ideal $\mathrm{Mg}, \mathrm{Ca}$, and $\mathrm{K}$ demand of AR derived from databases of biomass nutrient content. Balanced nutrient supply is necessary to avoid shift of growth limitation to other nutrients, which can occur according to Liebig's law (von Liebig and Playfair, 1843). Shift of growth limitation to other nutrients is observed for some US forests that changed from an N-limited to a P-limited system after an increase in atmospheric $\mathrm{N}$ deposition (Crowley et al., 2012). Based on minimum and maximum harvest rates of bioenergy grass (BG), we estimated the related $\mathrm{P}$ and $\mathrm{K}$ export by harvest from the fields. We decided on these nutrients for $\mathrm{BG}$ since crops require large amounts of $\mathrm{K}$ and $\mathrm{P}$, once $\mathrm{N}$ demand is covered. The amount of rock powder required for enhanced weathering (EW) to cover projected $\mathrm{P}$ gaps and to replenish exported nutrients was estimated. The projected impacts on soil hydrology due to EW deployment were carried out by pedotransfer functions since they are used to estimate soil hydraulic properties (Schaap et al., 2001; Whitfield and Reid, 2013; Wösten et al., 2001) and such approximations have proven to be a suitable approach (Vienken and Dietrich, 2011).

The additional AR P demand, obtained for the 21st century for an N-unlimited and N-limited AR scenario (Kracher, 2017), was approximated by stoichiometric $P: N$ ratios for mean and range (5th and 95th percentiles), which is a similar approach to that of Sun et al. (2017). The ratios were derived from databases of hardwood and softwood (Pardo et al., 2005) and foliar biome-specific nutrient content (Vergutz et al., 2012). We then compared the inferred $\mathrm{P}$ demand to geogenic $\mathrm{P}$ supply given by observation-based estimates of soil inorganic labile P and organic P (Yang et al., 2014a); observation-based estimates of $\mathrm{P}$ release (Hartmann et al., 2014) from weathering corrected to future temperature increases, since the uncertainty in the future hydrological cycle is too high (Goll et al., 2014); and estimated atmospheric P depositions from Wang et al. (2017) to derive the potential geogenic P deficits (i.e, the P gap) during the 21st century. Since the geogenic $\mathrm{P}$ supply cannot cope with N-stock-based $\mathrm{P}$ demand from the different AR scenarios within $\mathrm{P}$ gapped areas, the biomass production and biomass $\mathrm{C}$ sequestration, predicted by the AR scenarios, will be lower. Based on the amount of missing $\mathrm{P}$, we estimated the $\mathrm{C}$-stock reduction within $\mathrm{P}$ gapped areas by using stoichiometric $\mathrm{C}: \mathrm{P}$ ratios. The $\mathrm{C}: \mathrm{P}$ ratios were derived from simulated $\mathrm{C}$-stock content (Kracher, 2017) and inferred N-stock-based P demand.

Necessary $\mathrm{Mg}, \mathrm{Ca}$, and $\mathrm{K}$ supply for balanced tree nutrition based on $\mathrm{P}$ supply was derived from $\mathrm{N}$-stock-based $\mathrm{Mg}, \mathrm{Ca}$, and $\mathrm{K}$ additional demand normalized to the $\mathrm{N}$-stockbased additional $\mathrm{P}$ demand (Fig. 1). The nutrient demand of bioenergy grass was estimated based on stoichiometric $\mathrm{P}: \mathrm{N}$ and $\mathrm{K}: \mathrm{N}$ ratios, used in Bodirsky et al. (2012), for minimum and maximum exported $\mathrm{N}$ proportional to harvest rates of the 1995-2090 period obtained from the agricultural production model MAgPIE (Fig. 1). Later on, the necessary amount of rock to cover the $\mathrm{P}$ gaps of the AR scenario and to resupply the nutrients exported by BG harvest was estimated (Fig. 1). In addition, the potential impact of deploying rock powder into the topsoil hydrology was modeled.

\subsection{Global land-system model output}

\subsubsection{Afforestation and reforestation}

The idealized simulations for the AR system from Kracher (2017) performed by the land surface model JSBACH (Reick et al., 2013) for RCP4.5 were used (Thomson et al., 2011). The RCP4.5 scenario assumes that the emissions peak is around 2040 and considers that forest lands expand from their present-day extent (Thomson et al., 2011). The coupled terrestrial nitrogen-carbon cycle model assumes $\mathrm{N}$-unlimited and $\mathrm{N}$-limited conditions and considers harvest rates and transitions between different anthropogenic and natural land cover types (Hurtt et al., 2011) for a Gaussian grid of approximately $2^{\circ} \times 2^{\circ}$ resolution. Accounting for the $\mathrm{N}$ cycle reduces the uncertainty in atmospheric carbon sequestration prediction by AR models (Zaehle and Dalmonech, 2011). In JSBACH, the N supply for plants is controlled by competition between plants and decomposing microbes, while other numerical models prioritize immobilization or plant growth (Achat et al., 2016).

The net primary productivity (NPP) calculation was based on atmospheric $\mathrm{CO}_{2}$ concentrations, stomatal conductance, and water availability. JSBACH considers mass conservation, a supply-demand ansatz, and fixed $\mathrm{C}: \mathrm{N}$ ratios (Goll 


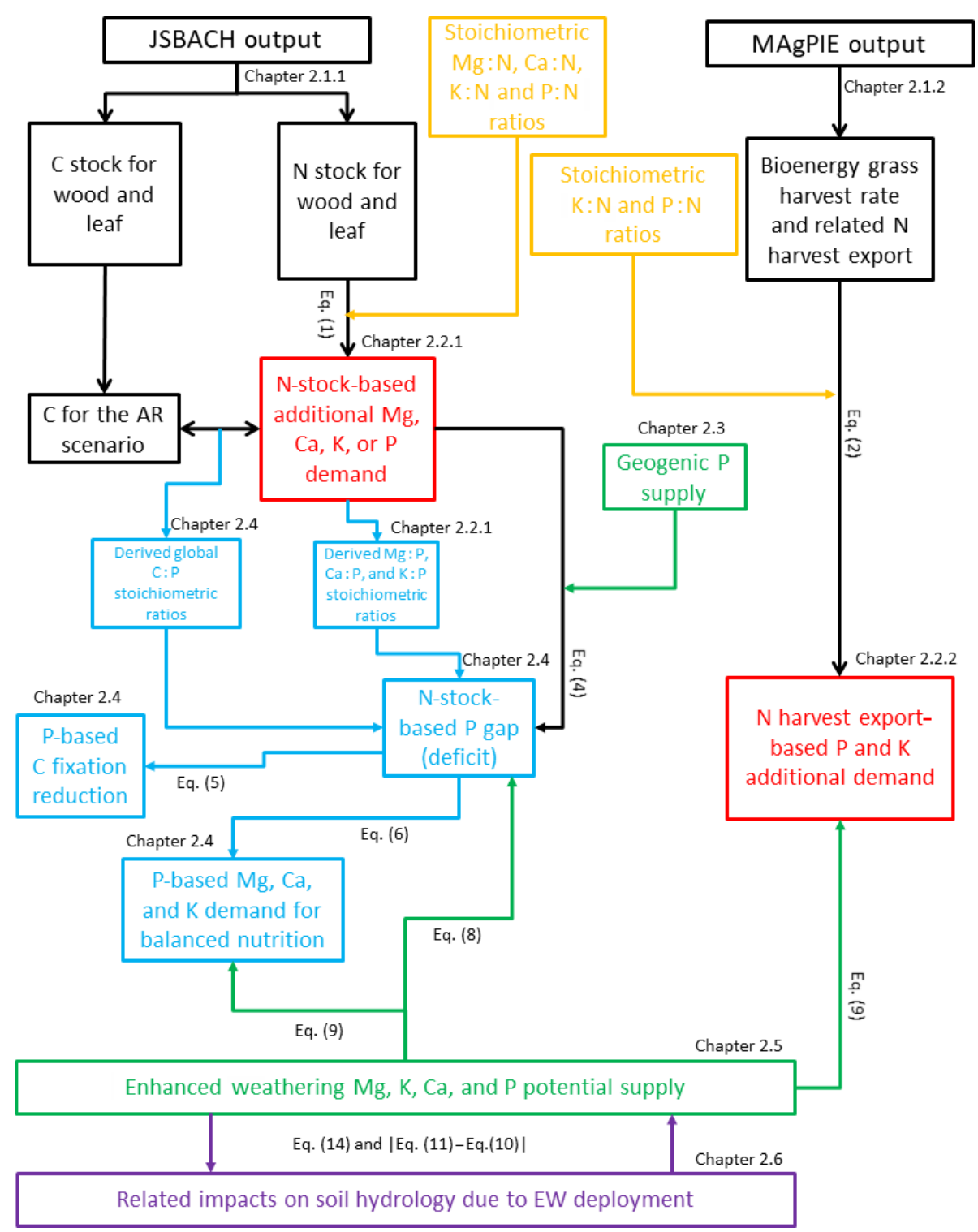

Figure 1. Schematic steps and datasets used to derive geogenic nutrient demand from simulated biomass changes; $\mathrm{P}$ gaps; reduced $\mathrm{C}$ sequestration; and $\mathrm{Ca}, \mathrm{K}$, and $\mathrm{Mg}$ supply for balanced tree nutrition. Black colors: outputs from land surface model JSBACH and agricultural production model MAgPIE. Yellow colors: stoichiometric $\mathrm{Mg}: \mathrm{N}, \mathrm{Ca}: \mathrm{N}, \mathrm{K}: \mathrm{N}$, and $\mathrm{P}: \mathrm{N}$ ratios used to obtain the N-stock-based nutrient demand. Red colors: N-stock-based P, Mg, Ca, and K demand for wood and leaf (AR) or N harvest export-based P and K demand (BG). Green colors: nutrient supply from geogenic sources (atmospheric $\mathrm{P}$ deposition and different soil $\mathrm{P}$ pools) or from enhanced weathering. Blue colors: derived P gap for AR; derived stoichiometric C : P, Mg : P, Ca : P, and K : P ratios; P-based C-fixation reduction; and P-based $\mathrm{Mg}, \mathrm{Ca}$, and K supply for balanced tree nutrition. Purple colors: related EW deployment impacts on soil hydrology estimated by pedotransfer functions. AR: afforestation-reforestation; BG: bioenergy grass.

et al., 2012). The coupled terrestrial nitrogen-carbon cycle model was selected since it (i) considered forest regrowth on abandoned croplands (which in the long term become acidic and consequently favor leaching of nutrients and heavy metals; Hesterberg, 1993), (ii) considered natural shift in natural vegetation, (iii) considered a natural $\mathrm{N}$ supply scenario $(\mathrm{N}-$ limited) and an $\mathrm{N}$-fertilized scenario (N-unlimited), (iv) con- sidered future $\mathrm{CO}_{2}$ increase leading to $\mathrm{CO}_{2}$ fertilization, and (v) explicitly considered large-scale afforestation.

We retrieved the annual changes in $\mathrm{N}$ and $\mathrm{C}$ content of different pools, i.e., wood (above and below ground, also including litter) and foliar (above and below ground, also including litter) for temperate, cold, tropical, and subtropical plant functional types climate growing forests and shrubs for the years 2006-2099 and annual model output. 


\subsubsection{Biomass production from bioenergy grass}

Simulations of BG nutritional needs from the agricultural production model MAgPIE, a framework for modeling global land systems (Dietrich et al., 2018; Lotze-Campen et al., 2008; Popp et al., 2010), were used. The objective of MAgPIE is to minimize total costs of production for a given amount of regional food and bioenergy demand and a given climate target (here RCP4.5 to correspond to the AR simulations). In its biophysical core, the yields in the model are based on LPJmL (Bondeau et al., 2007; Beringer et al., 2011; Müller and Robertson, 2013), a dynamic global vegetation model, which is designed to simulate vegetation composition and distribution for both natural and agricultural ecosystems.

At the starting point of the simulation, the LPJmL bioenergy grass yields have been scaled using agricultural land use intensity levels (Dietrich et al., 2012) for different world regions accounting for the yield gap between potential and observed yields for the period 1995-2005. For the future yields (2005-2090), the development is then driven by investments into yield-increasing technologies (Dietrich et al., 2014) based on the socioeconomic boundary conditions of the system.

The MAgPIE output had a frequency of $10 \mathrm{a}$, and the global minimum and maximum of each output year were taken to obtain the potential bioenergy grass minimum $\left(0.7 \mathrm{~kg} \mathrm{~m}^{-2} \mathrm{a}^{-1}\right)$ and maximum $\left(3.6 \mathrm{~kg} \mathrm{~m}^{-2} \mathrm{a}^{-1}\right)$ harvest rate for the simulation period for the areas with bioenergy plantations.

\subsection{Nutrient demand}

\subsubsection{Afforestation and reforestation}

The $\mathrm{P}, \mathrm{Mg}, \mathrm{Ca}$, and $\mathrm{K}$ additional demand is defined as the amount of $\mathrm{P}, \mathrm{Mg}, \mathrm{Ca}$, and $\mathrm{K}$ needed to realize the state of ecosystem $\mathrm{N}$ variables in each grid cell and year according to JSBACH output (Fig. 1). It was estimated from the spatially explicit information on average forest $\mathrm{N}$ content of each stock and plant functional type for an N-unlimited and an $\mathrm{N}$ limited AR scenario from Kracher (2017). Since P limits forest growth in a wide range of ecosystems (Elser et al., 2007), we performed a $\mathrm{P}$ budget for each $\mathrm{AR}$ scenario. The ideal $\mathrm{P}, \mathrm{Mg}, \mathrm{Ca}$, and $\mathrm{K}$ biomass additional demands were based on the difference in the simulated change in $\mathrm{N}$ pools at that time with respect to the simulation year of 2006 multiplied by their corresponding $\mathrm{Mg}: \mathrm{N}, \mathrm{Ca}: \mathrm{N}, \mathrm{K}: \mathrm{N}$, or $\mathrm{P}: \mathrm{N}$ ratios $\left(r_{i j}\right)$ and were calculated following Eq. (1):

$\Delta M_{\mathrm{pool}, i}=\sum_{j=1}^{n} \Delta N_{i j} \times r_{i j}$

where $\Delta M_{\text {pool, } i}\left(\mathrm{~kg} \mathrm{~m}^{-2} \mathrm{a}^{-1}\right)$ is the average $\mathrm{N}$-stock-based $\mathrm{Mg}, \mathrm{Ca}, \mathrm{K}$, or $\mathrm{P}$ demand for a given time in the future simulation time range (2007-2099) within a cell for biome $i . \Delta N_{i j}$ $\left(\mathrm{kg} \mathrm{m}^{-2} \mathrm{a}^{-1}\right)$ is the average $\mathrm{N}$-stock change in pool $j$. The number of $\mathrm{N}$ pools is $n$. The $\mathrm{N}$ pools considered are wood
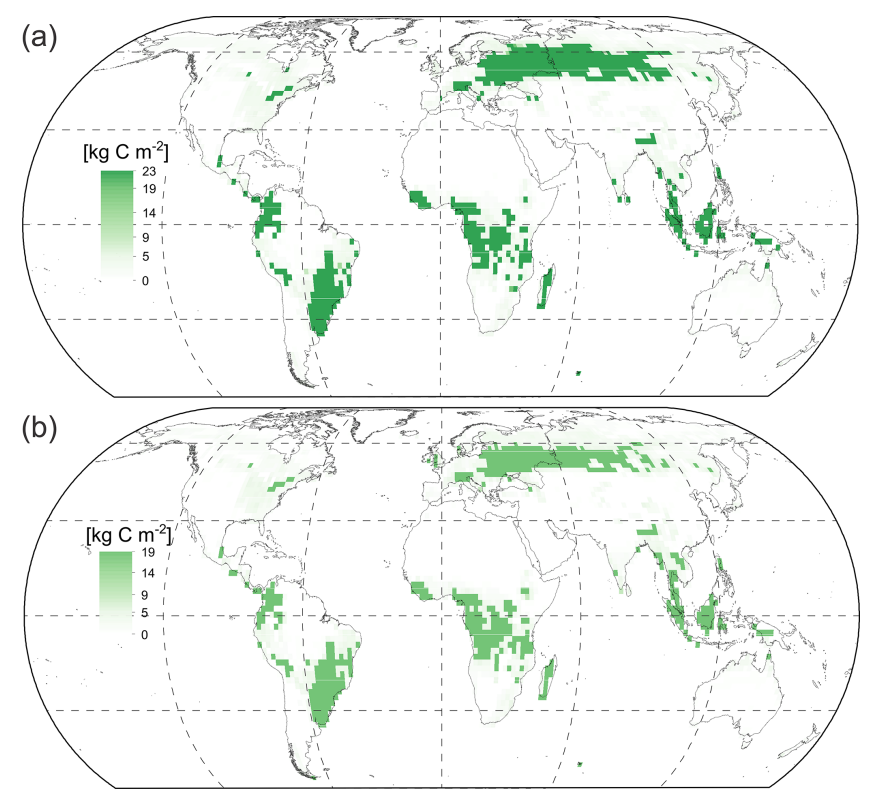

Figure 2. Carbon sequestered in different afforestationreforestation scenarios for the 21st century period (2006-2099) for an RCP4.5 scenario, according to Kracher (2017). (a) For an $\mathrm{N}$-unlimited AR scenario the global C sequestration is $224 \mathrm{GtC}$. (b) For an N-limited AR scenario the global $\mathrm{C}$ sequestration is 190 Gt C. (C) ESRI.

(above and below ground, including litter) and foliar (above and below ground, including litter).

The P, Mg, Ca, K, and $\mathrm{N}$ content of leaves obtained from a global leaf chemistry database (Vergutz et al., 2012) was used to derive the $\mathrm{Mg}: \mathrm{N}, \mathrm{Ca}: \mathrm{N}, \mathrm{K}: \mathrm{N}$, or $\mathrm{P}: \mathrm{N}$ ratios $(\mathrm{Ta}-$ ble 1), which were already biome classified. For wood, the tree chemical composition database of US forests (Pardo et al., 2005) was used in order to derive the global ratios, which were assumed to represent the chemical composition of all biomes (Table 1).

The AR C content (Fig. 2) from Kracher (2017) and the resulting $\mathrm{N}$-stock-based $\mathrm{Mg}, \mathrm{Ca}$, and $\mathrm{K}$ demand were normalized by the $\mathrm{N}$-stock-based $\mathrm{P}$ demand to estimate the mean and range of the $\mathrm{C}: \mathrm{P}, \mathrm{Mg}: \mathrm{P}, \mathrm{Ca}: \mathrm{P}$, and $\mathrm{K}: \mathrm{P}$ ratios of each grid cell. The stoichiometric $\mathrm{C}: \mathrm{P}, \mathrm{Mg}: \mathrm{P}, \mathrm{Ca}: \mathrm{P}$, and $\mathrm{K}: \mathrm{P}$ ratios were used to derive the $\mathrm{C}$-fixation reduction due to $\mathrm{P}$ deficiencies and the necessary $\mathrm{Mg}, \mathrm{Ca}$, and $\mathrm{K}$ supply for a balanced biomass nutrition based on supplied P (Fig. 1).

\subsubsection{Biomass production from bioenergy grass}

The BG yield was obtained by the spatially explicit harvest rates within a grid cell for an output frequency of $10 \mathrm{a}$ and a period of 95 a (1995-2090). The minimum 0.7 and maximum $3.6 \mathrm{~kg} \mathrm{~m}^{-2} \mathrm{a}^{-1}$ harvest rates were used. With the information on exported $\mathrm{N}$ by each harvest rate, the exported $\mathrm{K}$ or $\mathrm{P}$ from cultivation fields (Eq. 2) was estimated based on the $\mathrm{P}: \mathrm{N}$ and $\mathrm{K}: \mathrm{N}$ stoichiometric ratios used in Bodirsky et al. (2012). We 
Table 1. Stoichiometric parameters for different pools and biomes used in this study.

\begin{tabular}{|c|c|c|c|c|c|c|c|c|c|c|c|c|c|c|c|c|}
\hline \multirow{2}{*}{$\frac{\text { Biome }}{\text { Leaf }^{b}}$} & & \multicolumn{5}{|c|}{ Tropical evergreen } & \multicolumn{5}{|c|}{ Tropical deciduous } & \multicolumn{5}{|c|}{ Temperate evergreen } \\
\hline & & Mean & SD & $n$ & $\begin{array}{r}5 \text { th } \\
\text { percentile }\end{array}$ & $\begin{array}{r}95 \text { th } \\
\text { percentile }\end{array}$ & Mean & SD & $n$ & $\begin{array}{r}5 \text { th } \\
\text { percentile }\end{array}$ & $\begin{array}{r}95 \text { th } \\
\text { percentile }\end{array}$ & Mean & SD & $n$ & $\begin{array}{r}5 \text { th } \\
\text { percentile }\end{array}$ & $\begin{array}{r}95 \text { th } \\
\text { percentile }\end{array}$ \\
\hline $\mathrm{C}: \mathrm{N}$ & $(-)$ & 29.72 & 15.01 & 4 & 16.33 & 46.49 & $26.96^{\mathrm{a}}$ & $10.53^{\mathrm{a}}$ & $171^{\mathrm{a}}$ & $14.50^{\mathrm{a}}$ & $46.7^{\mathrm{a}}$ & 49.11 & 12.15 & 8 & 33.54 & 65.69 \\
\hline$P: N$ & & 0.06 & 0.02 & 59 & 0.04 & 0.10 & 0.07 & 0.03 & 43 & 0.04 & 0.13 & 0.09 & 0.03 & 23 & 0.05 & 0.13 \\
\hline $\mathrm{K}: \mathrm{N}$ & & 0.97 & 0.80 & 2 & 0.46 & 1.48 & 1.26 & 0.93 & 22 & 0.23 & 2.45 & 0.47 & 0.09 & 12 & 0.33 & 0.58 \\
\hline $\mathrm{Ca}: \mathrm{N}$ & & 2.73 & 3.44 & 2 & 0.54 & 4.91 & 1.55 & 0.78 & 22 & 0.52 & 2.90 & $0.73^{\mathrm{a}}$ & $0.67^{\mathrm{a}}$ & $150^{\mathrm{a}}$ & $0.16^{\mathrm{a}}$ & $1.94^{\mathrm{a}}$ \\
\hline $\mathrm{Mg}: \mathrm{N}$ & & 0.40 & 0.52 & 2 & 0.07 & 0.73 & 0.37 & 0.29 & 22 & 0.10 & 0.83 & $0.21^{\mathrm{a}}$ & $0.21^{\mathrm{a}}$ & $115^{\mathrm{a}}$ & $0.05^{\mathrm{a}}$ & $0.66^{\mathrm{a}}$ \\
\hline Wood $^{\mathrm{c}}$ & & Mean & SD & $n$ & $\begin{array}{r}5 \text { th } \\
\text { percentile }\end{array}$ & $\begin{array}{r}95 \text { th } \\
\text { percentile }\end{array}$ & Mean & $\mathrm{SD}$ & $n$ & $\begin{array}{r}5 \text { th } \\
\text { percentile }\end{array}$ & $\begin{array}{r}\text { 95th } \\
\text { percentile }\end{array}$ & Mean & SD & $n$ & $\begin{array}{r}5 \text { th } \\
\text { percentile }\end{array}$ & $\begin{array}{r}95 \text { th } \\
\text { percentile }\end{array}$ \\
\hline $\mathrm{C}: \mathrm{N}$ & $(-)$ & 235 & 244 & 9 & 56 & 610 & 235 & 244 & 9 & 56 & 610 & 235 & 244 & 9 & 56 & 610 \\
\hline$P: N$ & & 0.15 & 0.20 & 684 & 0.04 & 0.30 & 0.15 & 0.20 & 684 & 0.04 & 0.30 & 0.15 & 0.20 & 684 & 0.04 & 0.30 \\
\hline $\mathrm{K}: \mathrm{N}$ & & 0.60 & 0.40 & 700 & 0.20 & 1.20 & 0.60 & 0.40 & 700 & 0.20 & 1.20 & 0.60 & 0.40 & 700 & 0.20 & 1.20 \\
\hline $\mathrm{Ca}: \mathrm{N}$ & & 1.80 & 1.30 & 705 & 0.40 & 4.30 & 1.80 & 1.30 & 705 & 0.40 & 4.30 & 1.80 & 1.30 & 705 & 0.40 & 4.30 \\
\hline $\mathrm{Mg}: \mathrm{N}$ & & 0.20 & 0.10 & 681 & 0.10 & 0.40 & 0.20 & 0.10 & 681 & 0.10 & 0.40 & 0.20 & 0.10 & 681 & 0.10 & 0.40 \\
\hline Biome & & \multicolumn{5}{|c|}{ Temperate deciduous } & \multicolumn{5}{|c|}{ Shrubs raingreen } & \multicolumn{5}{|c|}{ Shrubs deciduous } \\
\hline Leaf $^{b}$ & & Mean & SD & $n$ & $\begin{array}{r}5 \text { th } \\
\text { percentile }\end{array}$ & $\begin{array}{r}95 \text { th } \\
\text { percentile }\end{array}$ & Mean & SD & $n$ & $\begin{array}{r}5 \text { th } \\
\text { percentile }\end{array}$ & $\begin{array}{r}95 \text { th } \\
\text { percentile }\end{array}$ & Mean & SD & $n$ & $\begin{array}{r}5 \text { th } \\
\text { percentile }\end{array}$ & $\begin{array}{r}95 \text { th } \\
\text { percentile }\end{array}$ \\
\hline $\mathrm{C}: \mathrm{N}$ & $(-)$ & 55.30 & 12.02 & 2 & 47.65 & 62.95 & 26.31 & 6.83 & 2 & 21.97 & 30.65 & $26.96^{\mathrm{a}}$ & $10.53^{\mathrm{a}}$ & $171^{\mathrm{a}}$ & $14.5^{\mathrm{a}}$ & $46.70^{\mathrm{a}}$ \\
\hline$P: N$ & & 0.08 & 0.03 & 32 & 0.04 & 0.13 & 0.07 & 0.01 & 2 & 0.06 & 0.08 & $0.08^{\mathrm{a}}$ & $0.05^{\mathrm{a}}$ & $662^{\mathrm{a}}$ & $0.04^{\mathrm{a}}$ & $0.16^{\mathrm{a}}$ \\
\hline $\mathrm{K}: \mathrm{N}$ & & 0.43 & 0.13 & 23 & 0.24 & 0.61 & 0.38 & 0.02 & 2 & 0.37 & 0.39 & $0.59^{\mathrm{a}}$ & $0.45^{\mathrm{a}}$ & $207^{\mathrm{a}}$ & $0.24^{\mathrm{a}}$ & $1.50^{\mathrm{a}}$ \\
\hline $\mathrm{Ca}: \mathrm{N}$ & & $0.73^{\mathrm{a}}$ & $0.67^{\mathrm{a}}$ & $150^{\mathrm{a}}$ & $0.16^{\mathrm{a}}$ & $1.94^{\mathrm{a}}$ & 0.44 & 0.08 & 2 & 0.39 & 0.50 & $0.73^{\mathrm{a}}$ & $0.67^{\mathrm{a}}$ & $150^{\mathrm{a}}$ & $0.16^{\mathrm{a}}$ & $1.94^{\mathrm{a}}$ \\
\hline $\mathrm{Mg}: \mathrm{N}$ & & $0.21^{\mathrm{a}}$ & $0.21^{\mathrm{a}}$ & $115^{\mathrm{a}}$ & $0.05^{\mathrm{a}}$ & $0.66^{\mathrm{a}}$ & 0.09 & 0.04 & 2 & 0.06 & 0.12 & $0.21^{\mathrm{a}}$ & $0.21^{\mathrm{a}}$ & $115^{\mathrm{a}}$ & $0.05^{\mathrm{a}}$ & $0.66^{\mathrm{a}}$ \\
\hline Wood $^{\mathrm{c}}$ & & Mean & SD & $n$ & $\begin{array}{r}5 \text { th } \\
\text { percentile }\end{array}$ & $\begin{array}{r}95 \text { th } \\
\text { percentile }\end{array}$ & Mean & $\mathrm{SD}$ & $n$ & $\begin{array}{r}5 \text { th } \\
\text { percentile }\end{array}$ & $\begin{array}{r}95 \text { th } \\
\text { percentile }\end{array}$ & Mean & SD & $n$ & $\begin{array}{r}5 \text { th } \\
\text { percentile }\end{array}$ & $\begin{array}{r}95 \text { th } \\
\text { percentile }\end{array}$ \\
\hline $\mathrm{C}: \mathrm{N}$ & $(-)$ & 235 & 244 & 9 & 56 & 610 & 235 & 244 & 9 & 56 & 610 & 235 & 244 & 9 & 56 & 610 \\
\hline$P: N$ & & 0.15 & 0.20 & 684 & 0.04 & 0.30 & 0.15 & 0.20 & 684 & 0.04 & 0.30 & 0.15 & 0.20 & 684 & 0.04 & 0.30 \\
\hline $\mathrm{K}: \mathrm{N}$ & & 0.60 & 0.40 & 700 & 0.20 & 1.20 & 0.60 & 0.40 & 700 & 0.20 & 1.20 & 0.60 & 0.40 & 700 & 0.20 & 1.20 \\
\hline $\mathrm{Ca}: \mathrm{N}$ & & 1.80 & 1.30 & 705 & 0.40 & 4.30 & 1.80 & 1.30 & 705 & 0.40 & 4.30 & 1.80 & 1.30 & 705 & 0.40 & 4.30 \\
\hline $\mathrm{Mg}: \mathrm{N}$ & & 0.20 & 0.10 & 681 & 0.10 & 0.40 & 0.20 & 0.10 & 681 & 0.10 & 0.40 & 0.20 & 0.10 & 681 & 0.10 & 0.40 \\
\hline
\end{tabular}

a Values obtained from all biomes. ${ }^{\mathrm{b}}$ Stoichiometric ratios derived from a global leaf chemistry database (Vergutz et al., 2012). ${ }^{\mathrm{c}}$ Stoichiometric ratios derived from a US softwood and hardwood database (Pardo et al., 2005). See file "S2.xlsx" in the Supplement for used database.

have chosen these nutrients since crops require large amounts of $\mathrm{K}$ and $\mathrm{P}$, once $\mathrm{N}$ demand is covered.

The simulated forests from the AR scenario are perennial, unlike bioenergy grasses which are completely harvested regularly due to their use as biomass feedstock for BECCS. Thus, the natural system's nutrient supply is insufficient for maintaining successive and constant yields, and the nutrients exported by harvest need to be replenished (Cadoux et al., 2012) to maintain high yields. The exported nutrients were calculated following Eq. (2):

$\mathrm{Bio}_{x}=r_{x} \times N_{\text {harvest }}$,

where $\mathrm{Bio}_{x}$ corresponds to the exported nutrient $\mathrm{P}$ or $\mathrm{K}$ $\left(\mathrm{kg} \mathrm{m}^{-2} \mathrm{a}^{-1}\right)$ by harvest. The $\mathrm{P}: \mathrm{N}$ or $\mathrm{K}: \mathrm{N}$ stoichiometric ratio used in Bodirsky et al. (2012) is $r_{x}$. $N_{\text {harvest }}$ is the exported $\mathrm{N}$ for a minimum 0.7 or a maximum $3.6 \mathrm{~kg} \mathrm{~m}^{-2} \mathrm{a}^{-1}$ harvest rate. The harvest rate value was based on the MAgPIE output for each grid cell, representing the minimum and maximum projected global harvest rate for a period of $95 \mathrm{a}$.

\subsection{Geogenic P supply for AR}

The geogenic $\mathrm{P}$ source databases have different spatial resolutions (Table 2); we resampled each of them to a coarser $2^{\circ} \times 2^{\circ}$ spatial resolution field by nearest-neighbor interpo- lation to minimize distortions of location (Pontius, 2000). The nearest-neighbor interpolation method reliably retains the overall proportions of an original fine-resolution map (Christman and Rogan, 2012). As the uncertainty in which $\mathrm{P}$ pool is available for long-term plant nutrition is high (Johnson et al., 2003), two scenarios for soil P supply were investigated: scenario one, considering $\mathrm{P}$ from weathering and atmospheric $\mathrm{P}$ deposition, and scenario two, the same as scenario one plus inorganic labile P and organic P (Yang et al., 2014a).

The atmospheric dry and wet $\mathrm{P}$ deposition rates were taken from simulation outputs for the 2006-2013 period and for the years 2030, 2050, and 2099 for an RCP4.5 scenario for a grid cell size of $1^{\circ}$ (Wang et al., 2017). The simulations were based on $\mathrm{P}$ emissions of sea salt, dust, biogenic aerosol particles, and $\mathrm{P}$ emitted by combustion processes and performed by the global aerosol chemistry-climate model LMDz-INCA (see Wang et al., 2017, for a detailed description of model and model assumptions). The simulation gaps were closed by linear regression, and the cumulative atmospheric $\mathrm{P}$ deposition was calculated by summing up the deposition rate of each cell for the 2006-2099 period according to Eq. (3):

$$
P_{\mathrm{tot}}=\sum_{i=2006}^{2099} P_{i}
$$


Table 2. Geogenic P sources used for each geogenic P supply scenario.

\begin{tabular}{llccl}
\hline P source & Resolution & $\begin{array}{c}\text { Geogenic P supply } \\
\text { scenario one }\end{array}$ & $\begin{array}{c}\text { Geogenic P supply } \\
\text { scenario two }\end{array}$ & Reference \\
\hline Soil organic P and inorganic labile P & $0.5^{\circ}$ & & $\mathrm{X}$ & Yang et al. (2014a) \\
Atmospheric P deposition & $1^{\circ}$ & $\mathrm{X}$ & $\mathrm{X}$ & Wang et al. (2017) \\
P from weathering & $1 \mathrm{~km}^{2}$ & $\mathrm{X}$ & $\mathrm{X}$ & Hartmann et al. (2014) \\
\hline
\end{tabular}

where $P_{\text {tot }}\left(\mathrm{kg} \mathrm{m}^{-2}\right)$ is the cumulative atmospheric $\mathrm{P}$ deposition of the 2006-2099 period (Fig. 3a). $P\left(\mathrm{~kg} \mathrm{~m}^{-2} \mathrm{a}^{-1}\right)$ is the atmospheric $\mathrm{P}$ deposition of each year $i$ within a grid cell.

The total soil P map from Yang et al. (2014a) was used to estimate the projected long-term available $\mathrm{P}$ in the soil system (Fig. 3b). The total P supply by weathering for the $21 \mathrm{st}$ century (2006-2099) was based on Hartmann et al. (2014) maps (Fig. 3c) that depict the chemical weathering as a function of runoff and lithology, corrected for temperature and soil thickness (Hartmann et al., 2014) and calibrated on 381 catchments in Japan (Hartmann et al., 2009). A relationship between air temperature and weathering rate was used, which was derived from reconstructed weathering rates and different climate change scenarios for the recent past (1860-2005) using the weathering model applied here. The relationship in which $\mathrm{P}$ weathering increases by $9 \%$ per $1{ }^{\circ} \mathrm{C}$ increase (Goll et al., 2014) implicitly accounts for changes in soil hydrology, without accounting for $\mathrm{P}$ concentration changes in primary and secondary $\mathrm{P}$ minerals. Due to the large uncertainties in projected changes in soil hydrology, we omitted a more detailed representation of hydrological effects on weathering.

\subsection{Estimating geogenic $P$ gap; related C-fixation reduction; and balanced $\mathrm{Mg}$, $\mathrm{Ca}$, and $\mathrm{K}$ supply for AR}

The potential $\mathrm{P}$ gap $\left(P_{\text {gap }}\left(\mathrm{kg} \mathrm{m}^{-2}\right)\right)$ was estimated as the difference between the mean and range (95th and 5th percentiles) of additional P demand estimated from the $\mathrm{N}$ stock for the two different AR scenarios (see Sect. 2.2.1) and the geogenic $\mathrm{P}$ supply from the different supply scenarios $\left(P_{\text {sup }}\right.$ $\left(\mathrm{kg} \mathrm{m}^{-2}\right)$ ) within the cover fraction for a grid cell of biome $i\left(f_{i}(-)\right)$, for the 21 st century (2006-2099) according to Eq. (4):

$P_{\text {gap }}=P_{\text {sup }} \times f_{i}-\Delta P_{\text {pool }, i}$

The plant C-fixation reduction was estimated based on the $\mathrm{P}$ gap and calculated following Eq. (5):

$C=r_{C} \times P_{\text {gap }}$

where $C\left(\mathrm{~kg} \mathrm{~m}^{-2}\right)$ is the reduced plant $\mathrm{C}$ fixation due to the projected $\mathrm{P}$ gap. The used stoichiometric $\mathrm{C}: \mathrm{P}$ ratio based on the mean and range (5th and 95th percentiles) chemistry for wood and leaves derived from the $\mathrm{N}$-limited and $\mathrm{N}$-unlimited AR scenario $\mathrm{N}$ stock as described in Sect. 2.2.1 is $r_{C}$.

The $\mathrm{Mg}$, Ca, and $\mathrm{K}$ necessary supply for balanced biomass nutrition $\left(M_{x}\left(\mathrm{~kg} \mathrm{~m}^{-2}\right)\right)$ should be proportional to the supplied $\mathrm{P}\left(P_{\mathrm{EW}}\left(\mathrm{kg} \mathrm{m}^{-2}\right)\right)$ and was calculated following Eq. (6):

$M_{x}=r_{x} \times P_{\mathrm{EW}}$,

with $P_{\text {EW }}$ being equal to the projected $P_{\text {gap }}$ since it is covered by $P$ from enhanced weathering according to Eq. (7).

$P_{\text {EW }}=P_{\text {gap }}$

where $r_{x}$ is the used stoichiometric ratio $\mathrm{Mg}: \mathrm{P}, \mathrm{Ca}: \mathrm{P}$, or $\mathrm{K}$ : $\mathrm{P}$ obtained by normalizing the $\mathrm{N}$-stock-based additional $\mathrm{Mg}, \mathrm{Ca}$, and $\mathrm{K}$ demand to the $\mathrm{N}$-stock-based additional $\mathrm{P}$ demand.

\subsection{Enhanced weathering $\mathrm{Mg}, \mathrm{K}, \mathrm{Ca}$, and $\mathrm{P}$ potential supply}

To cover the potential of different igneous rocks for EW strategies, rhyolite and dacite (acidic rocks), andesite (intermediate rock), and basalt (basic rock) were selected to project necessary amounts to cover $\mathrm{P}$ gaps from the AR scenarios. Data on macronutrient concentrations $(\mathrm{Mg}, \mathrm{Ca}, \mathrm{K}, \mathrm{P})$ in weight percent within these rocks were downloaded from the EarthChem web portal (Fig. 4; http://www.earthchem. org, last access: 14 July 2017). The data were selected for rocks categorized as rhyolite, dacite, andesite, and basalt, neglecting intermediate compositions between different lithotypes (i.e., a trachybasalt that has its chemical composition lying between trachyte and basalt). Rocks that were under any metamorphism grade (e.g., metabasalt) were neglected because metamorphism can change rock mineralogy. We neglected rocks known to have a high content of minerals rich in trace elements (e.g., an alkali basalt can have a $\mathrm{P}$ concentration > 3000 ppm (Porder and Ramachandran, 2013), but it is rich in olivine (John, 2001; Irvine and Baragar, 1971), which contains elevated concentrations of nickel and chromium (Edwards et al., 2017)). Nickel and chromium are trace elements problematic for agriculture (Edwards et al., 2017). Thus, following the classification criteria, the numbers of selected data to calculate descriptive statistics for $\mathrm{Mg}, \mathrm{Ca}, \mathrm{K}$, and $\mathrm{P}$ content within rocks were 2985 chemical analyses for rhyolite, 3008 chemical analyses for dacite, 
(a)

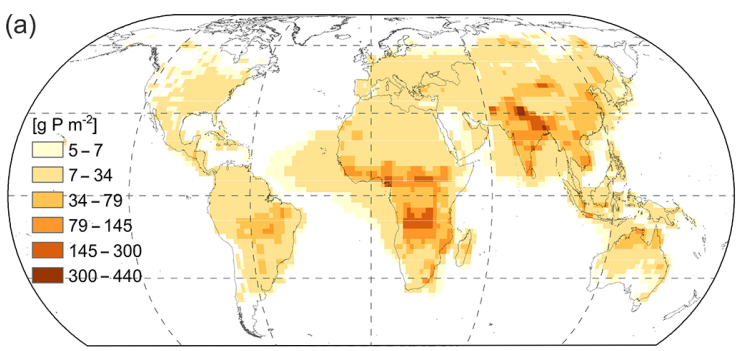

(c)

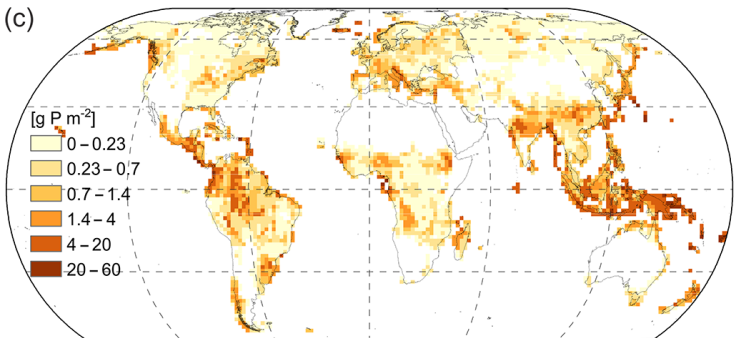

(b)

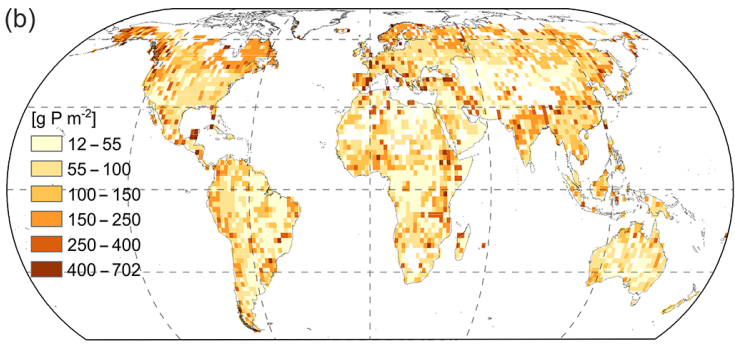

Figure 3. Different sources of geogenic P. (a) Cumulative atmospheric P deposition for 2006-2099 according to Wang et al. (2017). (b) Total inorganic labile $\mathrm{P}$ and organic $\mathrm{P}$ in the soil up to a depth of $0.5 \mathrm{~m}$ according to Yang et al. (2014a). (c) Cumulative weathering P release for the 21st century (2006-2099) based on Hartmann et al. (2014), accounting for weathering rate changes related to temperature increase (Goll et al., 2014). (C) ESRI.

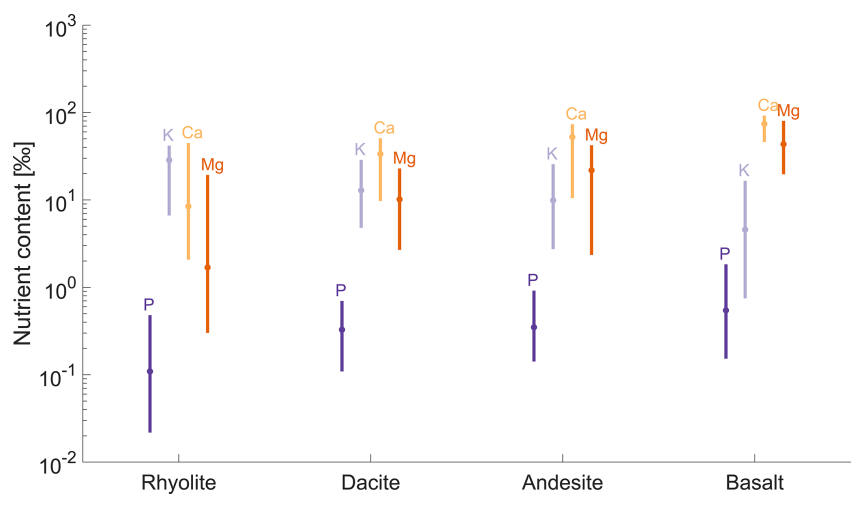

Figure 4. Statistical data of major element concentration in rocks with median values (filled circles) and range (5th and 95th percentiles; whiskers). Values from EarthChem web portal (http:// www.earthchem.org, last access: 14 July 2017). The numbers of chemical analyses used to calculate the descriptive statistics were 2985 chemical analyses for rhyolite, 3008 chemical analyses for dacite, 11099 chemical analyses for andesite, and 23816 chemical analyses for basalt.

11099 chemical analyses for andesite, and 23816 chemical analyses for basalt.

The nutrient supply was estimated assuming complete rock powder dissolution in the system considering the median and range (5th or 95th percentile) of chemical composition. The duration of complete rock powder dissolution varies depending on the grain size (i.e., 1 a for grain sizes between 0.6 and $90 \mu \mathrm{m}$ for basalt; Strefler et al., 2018). The results and discussion will focus on basalt rock powder considering median $P$ values $(500 \mathrm{ppm})$ and range (5th
(157 ppm) and 95th (1833 ppm) percentiles), as basalt is abundant worldwide (Amiotte Suchet et al., 2003; Börker et al., 2019) and has a high $P$ content compared to acidic and intermediate rocks (Porder and Ramachandran, 2013). Median $\mathrm{P}$ concentration can be $>3000 \mathrm{ppm}$ for alkali basalts, but for a broader basalt classification that considered 97895 samples, it can be 916 ppm (Porder and Ramachandran, 2013). The necessary mass of rock powder to supply macronutrients ( $\mathrm{Mg}, \mathrm{Ca}, \mathrm{K}$, or P) was calculated following Eq. (8):

$R_{d}=\frac{M_{\mathrm{ex}}}{f_{\mathrm{nut}}}$

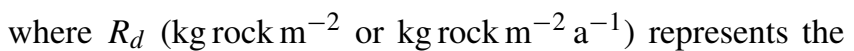
mass of a rock type to cover AR or BG nutritional needs, $M_{\text {ex }}\left(\mathrm{kg} \mathrm{m}^{-2}\right.$ or $\left.\mathrm{kg} \mathrm{m}^{-2} \mathrm{a}^{-1}\right)$ is the mass of required nutrient for AR or BG (e.g., $P$ to cover a $P_{\text {gap }}$ obtained by Eq. 4), and $f_{\text {nut }}(-)$ is the median and range (5th or 95 th percentile) fractions of interest nutrient within the selected rock.

However, the potential nutrient supply by EW for different amounts of rock powder being deployed was also estimated following Eq. (9):

$\mathrm{Nut}_{\text {in }}=M_{\text {rock }} \times f_{\text {nut }}$,

where Nut $\mathrm{in}_{\text {in }}\left(\mathrm{kg} \mathrm{m}^{-2}\right.$ or $\left.\mathrm{kg} \mathrm{m}^{-2} \mathrm{a}^{-1}\right)$ represents the macronutrient input by dissolving a chosen rock. $M_{\text {rock }}\left(\mathrm{kg} \mathrm{rock} \mathrm{m}^{-2}\right.$

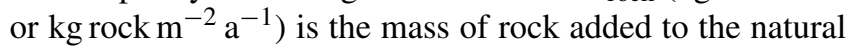
system. 


\subsection{Related impacts on soil hydrology from enhanced weathering deployment}

Large-scale deployment of rock powder on soils is expected to influence its texture. The deployed amount and texture of rock powder will somehow affect hydraulic conductivity, water retention capacity, and specific soil surface area. Pedotransfer functions (PTFs) are used to estimate soil hydraulic properties (Schaap et al., 2001; Whitfield and Reid, 2013; Wösten et al., 2001), and such approximations have proven to be a suitable approach (Vienken and Dietrich, 2011). PTFs make use of statistical analysis (Saxton and Rawls, 2006; Wösten et al., 2001), artificial neural networks, and other methods applied to large soil databases of measured data (Wösten et al., 2001). The equations from Saxton et al. (1986) performed the best estimations of soil hydraulic properties (Gijsman et al., 2002). Later on, Saxton and Rawls (2006) improved Saxton et al. (1986) PTFs, and they are used to estimate the effects on soil hydraulic properties due to deployment of basalt powder (Eqs. 10-18).

The potential changes in soil hydraulic properties, due to the application of a fine basalt texture (15.6\% clay, $83.8 \%$ silt, and $0.6 \%$ fine sand) or a coarse basalt texture $(15.6 \%$ clay, $53.8 \%$ silt, and $30.6 \%$ fine sand), were estimated as a function of rock powder deployment for soils corresponding to $\mathrm{P}$ gap areas from the $\mathrm{N}$-unlimited AR scenario. According to the international organization for standardization, the synthetic materials can be classified according to their grain sizes; therefore, here the clay comprises grain diameters $\leq 2 \mu \mathrm{m}$, silt comprises grain diameters $2-63 \mu \mathrm{m}$, and fine sand comprises grain diameters $63-200 \mu \mathrm{m}$ (ISO 14688$1: 2002,2002$ ), but since full dissolution is assumed, the ground basalt fine sand encompasses grain sizes of diameter $63-90 \mu \mathrm{m}$ remaining within the ISO 14688-1:2002 classification. The $\mathrm{N}$-unlimited AR scenario was selected since it would have the highest $\mathrm{P}$ deficiencies requiring more rock powder to cover the $\mathrm{P}$ gaps (i.e., it represents the maximum effect). The estimations are for a homogeneous mixture of rock powder and topsoil depth of $0.3 \mathrm{~m}$. Downward transport of fine-grained material is neglected for simplification. The considered values represent upper limits of rock powder application. The impacts on plant-available water (PAW) is given by the difference between water content at a pressure head of $-33 \mathrm{kPa}$ (Eq. 11) and $-1500 \mathrm{kPa}$ (Eq. 10), while the impact on soil hydraulic conductivity is given by (Eq. 14) (Saxton and Rawls, 2006):

$$
\begin{aligned}
& \theta_{1500}=\theta_{1500 t}+\left(0.14 \times \theta_{1500 t}-0.02\right) \\
& \theta_{33}=\theta_{33 t}+\left(1.283 \times\left(\theta_{33 t}\right)^{2}-0.374 \times\left(\theta_{33 t}\right)-0.015\right), \\
& \theta_{(S-33)}=\theta_{(S-33) t}+\left(0.636 \times \theta_{(S-33) t}-0.107\right) \\
& \theta_{S}=\theta_{33}+\theta_{(S-33)}-0.097 \times S+0.043 \\
& K_{\mathrm{S}}=1930 \times\left(\theta_{S}-\theta_{33}\right)^{(3-\lambda)}
\end{aligned}
$$

with

$$
\begin{aligned}
& \theta_{1500 t}=-0.024 \times S+0.487 \times C+0.006 \times \mathrm{OM} \\
&+ 0.005 \times(S \times \mathrm{OM})-0.013(C \times \mathrm{OM}) \\
&+0.068(S \times C)+0.031, \\
& \theta_{33 t}=-0.251 \times S+0.195 \times C+0.011 \times \mathrm{OM} \\
&+ 0.006 \times(S \times \mathrm{OM})-0.027 \times(C \times \mathrm{OM}) \\
&+ 0.452(S \times C)+0.299, \\
& \theta_{(S-33) t}=0.278 \times S+0.034 \times C+0.022 \times \mathrm{OM} \\
& \quad-0.018 \times(S \times \mathrm{OM})-0.027 \times(C \times \mathrm{OM}) \\
& \quad-0.584 \times(S \times C)+0.078, \\
& \lambda=\left[\frac{\ln (1500)-\ln (33)}{\ln \left(\theta_{33}\right)-\ln \left(\theta_{1500}\right)}\right]^{-1},
\end{aligned}
$$

where $S$ and $C$, respectively, represent the soil texture corresponding to sand and clay diameters (wt \%); OM is the soil organic matter (wt \%); and the moisture (wt $\%$ ) is estimated by $\theta_{1500}$ and $\theta_{33}$, respectively, representing the soil moisture for a pressure head of $-1500 \mathrm{kPa}\left(R^{2}=0.86\right)$ and $-33 \mathrm{kPa}$ $\left(R^{2}=0.63\right) . \theta_{(S-33)}$ and $\theta_{S}$, respectively, correspond to the $0 \mathrm{kPa}$ to $-33 \mathrm{kPa}$ moisture $\left(R^{2}=0.36\right)$, and to the saturated $(0 \mathrm{kPa})$ moisture $\left(R^{2}<0.25\right) . K_{\mathrm{S}}\left(\mathrm{mm} \mathrm{h}^{-1}\right)$ represents the saturated soil hydraulic conductivity, and $\lambda$ is the slope of the logarithmic tension-moisture curve. The numbers in front of each described variable are regression coefficients (Saxton and Rawls, 2006).

The initial hydrologic properties of topsoil were estimated for a depth of $0.3 \mathrm{~m}$, as it is the average depth at which usual machinery can homogeneously mix topsoil (Fageria and Baligar, 2008). Greater depths can be reached but under higher energy and labor costs (Fageria and Baligar, 2008). The global dataset of derived soil properties (Batjes, 2005), which had textural information (sand, silt, and clay content) for shallow soil depths $(0.3 \mathrm{~m})$, was used. The raster had a resolution of $0.5^{\circ}$, and the soil properties for the interest areas of biomass growth limitation (the same as the areas displayed in Fig. S7a in the Supplement) were included by a spatial join (using Esri ArcMap 10.8). The nutrient-deficient areas encompass soils of different textures and organic matter content, which had their initial $K_{\mathrm{S}}$ estimated separately based on Eq. (14). The sum of clay, silt, and sand fractions within each cell should always be a unity and were corrected when necessary by Eq. (19):

$G_{\text {cor }}=\frac{\left(G_{\text {ini }} \times M_{\text {soil_cell }}\right)}{\sum\left(G_{\text {ini }} \times M_{\text {soil_cell }}\right)}$,

with

$M_{\text {soil_cell }}=V_{\text {cell }} \times \rho_{\text {bulk_cell }}$,

where $G_{\text {ini }}$ represents the initial topsoil texture (sand, silt, and clay content) of a specific raster cell $(-) . V_{\text {cell }}\left(\mathrm{km}^{3}\right)$ is the raster cell volume obtained by multiplying the area $\left(\mathrm{km}^{2}\right)$ 
to the soil depth of $0.3 \times 10^{-3} \mathrm{~km} . \rho_{\text {bulk_cell }}\left(\mathrm{kg} \mathrm{km}^{-3}\right)$ is the raster cell topsoil bulk density. $M_{\text {soil_cell }}(\mathrm{kg})$ is the total soil mass of a raster cell. $G_{\text {cor }}(-)$ is the corrected soil texture (sand, silt, and clay content).

The necessary rock powder mass was estimated by Eq. (8) to close the $P_{\text {gap }}$ obtained by Eq. (4). The effect of basalt powder application in soil $K_{\mathrm{S}}$ and PAW was estimated by assuming a homogeneous mixture between applied basalt powder and topsoil. The changes in initial soil organic matter (SOM) concentration within a raster grid cell were obtained by normalizing the SOM to the sum of applied basalt mass, mass of soil, and initial SOM mass by Eq. (21). This was necessary since the SOM concentration at the moment of basalt deployment would have a relative decrease compared to initial SOM concentration:

$\mathrm{OM}_{\mathrm{c}}=\frac{\mathrm{OM}_{\text {cell }}}{M_{\mathrm{b} \_ \text {cell }}+M_{\text {soil_cell }}+\mathrm{OM}_{\text {cell }}} \times 100$,

with

$\mathrm{OM}_{\text {cell }}=\mathrm{OM}_{\mathrm{wt}} \% \times M_{\text {soil_cell }}$,

where $\mathrm{OM}_{\mathrm{c}}(\mathrm{wt} \%)$ is the corrected soil organic matter content, $\mathrm{OM}_{\text {cell }}(\mathrm{kg})$ is the organic matter mass within the raster cell. $M_{\mathrm{b} \_c e l l}$ and $M_{\text {soil_cell }}$, both in kilograms, are the mass of basalt and mass of soil for a specific raster cell.

The impacts on soil texture by rock powder application considered the textures of applied basalt mass added to the initial soil mass by Eq. (23). A content of $15.6 \%$ clay, $83.8 \%$ silt, and $0.6 \%$ fine sand for fine basalt powder and $15.6 \%$ clay, $53.8 \%$ silt, and $30.6 \%$ fine sand for a coarse basalt powder was assumed.

$G_{\mathrm{bs}}=\frac{\left(G_{\mathrm{ini}} \times M_{\text {sed }_{\text {cell }}}+M_{\mathrm{b}_{\text {cell }}} \times G_{\text {basalt }}\right)}{\sum\left(G_{\text {ini }} \times M_{\text {sed }_{\text {cell }}}+M_{\mathrm{b}_{\text {cell }}} \times G_{\text {basalt }}\right)}$,

where $G_{\text {basalt }}$ corresponds to the texture fractions of the fine or coarse basalt powder. $G_{\mathrm{bs}}$ corresponds to the texture fractions of the resulting mixture of basalt plus soil. Thus, the texture fractions of the resulting mixture of basalt plus soil obtained by Eq. (23) were replaced within Eqs. (15-17) to estimate the impacts on soil hydraulic conductivity by Eq. (14) and PAW by subtracting the outcome from Eq. (11) to the outcome from Eq. (10), with clay size (grains $>1$ and $<3.9 \mu \mathrm{m}$ ) being the finest grain size we can consider.

Besides texture and organic matter, intrinsic grain properties (e.g., the shape of grains and pores, tortuosity, specific surface area, and porosity) should be considered (Bear, 1972). The equations from Beyer (1964) are based on the nonuniformity of grain size distribution and density of the grain packing to estimate soil properties. Carrier (2003) uses information on the particle grain size distribution, the particle shape, and the void ratio in his equations to estimate soil properties. However, such detailed information on a global scale is missing, making Beyer (1964) and Carrier (2003) equations not applicable to our analysis.

\section{Results}

\subsection{Afforestation and reforestation $P$ gaps and enhanced weathering as nutrient source}

The global $\mathrm{C}$ sequestration for the $\mathrm{N}$-limited AR scenario is $190 \mathrm{GtC}$, while for the $\mathrm{N}$-unlimited AR scenario it is $34 \mathrm{GtC}$ higher. The AR model from Kracher (2017) shows an increase in biomass production in tropical and temperate zones (Fig. 2). The results only focus on the N-limited scenario since it considered natural $\mathrm{N}$ supply, but the results for the N-unlimited scenario are presented in the Supplement (Sect. Bii). The calculated $\mathrm{P}$ budgets according to Eq. (4) for the AR time of 2006-2099 (Fig. 5) considered different geogenic supply scenarios (scenario one $-\mathrm{P}$ from weathering and atmospheric $\mathrm{P}$ deposition; scenario two the same as scenario one plus inorganic labile $\mathrm{P}$ and organic $\mathrm{P}$ ) and the average and range of the $\mathrm{N}$-stock-based $\mathrm{P}$ demand (calculated following Eq. 1) for the AR simulation from Kracher (2017).

The ideal $\mathrm{P}$ biomass additional demand (calculated from Eq. 1) to sequester $190 \mathrm{GtC}$ (N-limited AR scenario) amounts to $200 \mathrm{MtP}$ on a global scale for a mean wood and leaves $\mathrm{P}$ content; for the 5th and 95th percentile, the estimated P demand would be 71 and $345 \mathrm{MtP}$, respectively. The P budget (estimated from Eq. 4) for geogenic P supply scenario one suggests that $\mathrm{P}$ deficiency areas are distributed around the world but with more frequent occurrences in the Northern Hemisphere (Fig. 5a) and the $\mathrm{P}$ gaps can potentially reach up to $\sim 17 \mathrm{~g} \mathrm{P} \mathrm{m}^{-2}\left(\sim 4-\sim 30 \mathrm{~g} \mathrm{P} \mathrm{m}^{-2}\right.$ for the 5 th and 95th percentiles of wood and leaves chemistry; Table 3) or a global P gap of $\sim 77 \mathrm{MtP}\left(\sim 9-181 \mathrm{MtP}^{2}\right.$ for the 5th and 95th percentiles of wood and leaves chemistry; Table 3). However, for geogenic $\mathrm{P}$ supply scenario two, the $\mathrm{P}$ deficiency areas are predominantly located in the Southern Hemisphere (Fig. 5c) and the $\mathrm{P}$ gaps can potentially reach up to $\sim 7 \mathrm{~g} \mathrm{P} \mathrm{m}^{-2}\left(\sim 2-\sim 12 \mathrm{~g} \mathrm{P} \mathrm{m}^{-2}\right.$ for the 5th and 95th percentiles of wood and leaves chemistry; Table 3 ) or a global $\mathrm{P}$ gap of $\sim 10 \mathrm{MtP}\left(1-\sim 35 \mathrm{MtP}^{2}\right.$ for the 5th and 95th percentiles of wood and leaves chemistry; Table 3).

The $\mathrm{P}$ and $\mathrm{N}$ limitations cause an average $\mathrm{C}$ reduction of $47 \%$ for the geogenic P supply scenario one and $19 \%$ for the geogenic $\mathrm{P}$ supply scenario two (obtained by accounting for the $\mathrm{C}$ reduction from $\mathrm{N}$ limitation, which is $34 \mathrm{GtC}$ plus the $\mathrm{C}$ reduction from Table 3 , and then normalizing by the global sequestration for the $\mathrm{N}$-unlimited scenario of $224 \mathrm{GtC}$ ) or $\sim-1.1$ and $\sim-0.5 \mathrm{GtC} \mathrm{a}^{-1}$, respectively. In some areas, the $\mathrm{C}$ sequestration can be reduced by up to $100 \%$ compared to the predicted $\mathrm{C}$ sequestration of the AR models (Fig. 6). Accounting for $\mathrm{N}$ and $\mathrm{P}$ limitation on AR suggests that the biomass production will be affected, consequently decreasing the $\mathrm{C}$ sequestration potential of AR strategies (Table 3 and Fig. 6). Therefore, supplying the demanded $P$ would positively contribute to biomass reaching the predicted growth of the specific AR scenario. 
(a)

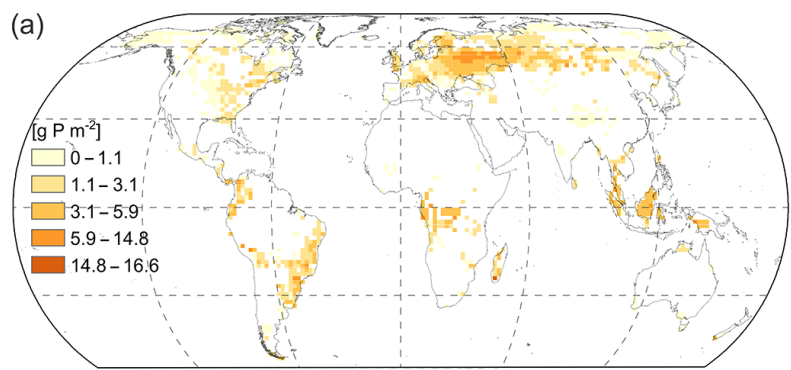

(c)

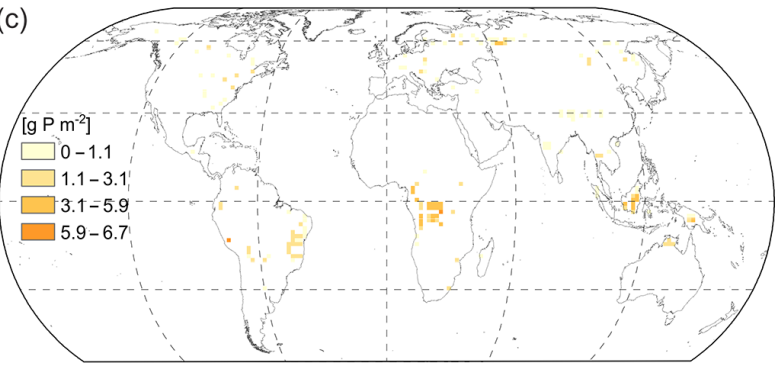

(b)

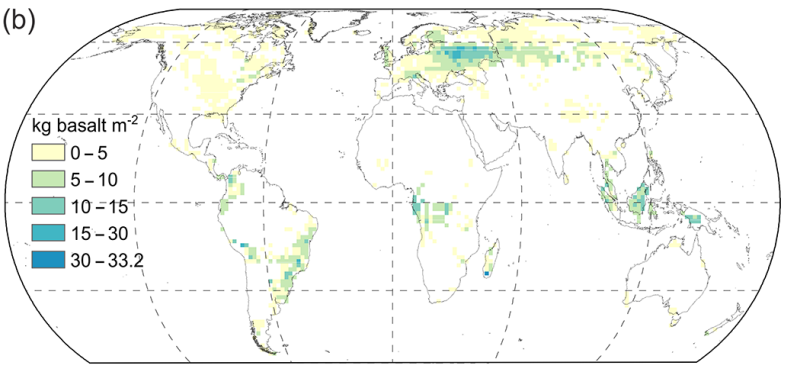

(d)

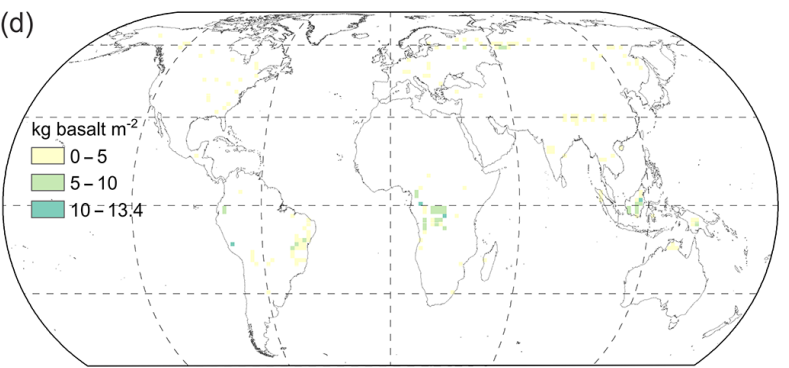

Figure 5. Areas with potential $\mathrm{P}$ gap for the nutrient budget of the N-limited AR scenario (after 94 a of simulation), assuming $\mathrm{P}$ concentrations within foliar and wood material corresponding to mean values (Table 1). (a) Geogenic P supply scenario one (geogenic P from weathering plus atmospheric $\mathrm{P}$ deposition as source of $\mathrm{P}$ ). (b) Basalt deployment necessary to close $\mathrm{P}$ gaps from $\mathrm{P}$ budget scenario of Fig. 5a. (c) Geogenic $\mathrm{P}$ supply scenario two (geogenic $\mathrm{P}$ from soil inorganic labile $\mathrm{P}$ and organic $\mathrm{P}$ pools plus atmospheric $\mathrm{P}$ deposition and $\mathrm{P}$ from weathering as source of P). (d) Basalt deployment necessary to close $\mathrm{P}$ gaps from $\mathrm{P}$ budget scenario of Fig. 5c. (C) ESRI.

Table 3. Global $\mathrm{P}$ gap, maximum estimated $\mathrm{P}$ gap, maximum $\mathrm{C}$ sequestration reduction, and global $\mathrm{C}$ reduction for the natural $\mathrm{N}$ supply (N-limited) AR scenario (projected C sequestration of $190 \mathrm{Gt} \mathrm{C}$ ).

\begin{tabular}{|c|c|c|c|c|c|c|c|c|c|c|c|c|c|}
\hline \multirow[t]{3}{*}{$\mathrm{N}$ supply } & \multirow[t]{3}{*}{$\begin{array}{l}\text { Geogenic P } \\
\text { supply }\end{array}$} & \multicolumn{3}{|c|}{$\begin{array}{l}\text { Maximum estimated P gap } \\
\qquad\left(\mathrm{g} \mathrm{P} \mathrm{m}^{-2}\right)\end{array}$} & \multicolumn{3}{|c|}{ Global P gap (Mt P) } & \multicolumn{3}{|c|}{$\begin{array}{l}\text { Maximum } \mathrm{C} \text { sequestration } \\
\text { reduction }\left(\mathrm{kg} \mathrm{C} \mathrm{m}^{-2}\right)\end{array}$} & \multicolumn{3}{|c|}{ Global C reduction (Gt C) } \\
\hline & & \multicolumn{12}{|c|}{ Wood and leaves $\mathrm{P}$ content } \\
\hline & & $\begin{array}{r}5 \text { th } \\
\text { percentile }\end{array}$ & Mean & $\begin{array}{r}95 \text { th } \\
\text { percentile }\end{array}$ & $\begin{array}{r}5 \text { th } \\
\text { percentile }\end{array}$ & Mean & $\begin{array}{r}\text { 95th } \\
\text { percentile }\end{array}$ & $\begin{array}{r}5 \text { th } \\
\text { percentile }\end{array}$ & Mean & $\begin{array}{r}95 \text { th } \\
\text { percentile }\end{array}$ & $\begin{array}{r}5 \text { th } \\
\text { percentile }\end{array}$ & Mean & $\begin{array}{r}95 \text { th } \\
\text { percentile }\end{array}$ \\
\hline \multirow[t]{2}{*}{ Limited } & Scenario one & 4.1 & 16.6 & 30.2 & 9.2 & 76.6 & 181.0 & 9.7 & 14.5 & 15.6 & 23.0 & 71.0 & 98.0 \\
\hline & Scenario two & 1.6 & 6.7 & 12.2 & 1.0 & 9.9 & 34.7 & 4.7 & 6.2 & 6.5 & 3.0 & 9.5 & 19.0 \\
\hline
\end{tabular}

Besides removing carbon from the atmosphere, EW can also amend soils by supplying nutrients and increasing alkalinity fluxes (Leonardos et al., 1987; Nkouathio et al., 2008; Beerling et al., 2018; Hartmann et al., 2013; Anda et al., 2015). Since basalt has higher $P$ content compared to acidic and intermediate rocks (Porder and Ramachandran, 2013), it could be used as raw material for EW to cover the estimated $\mathrm{P}$ gaps of Fig. 5a and c. For a median basalt $\mathrm{P}$ content of 500 ppm (cf., Sect. 2.5), it would be necessary to apply $\sim 33$ and $\sim 13 \mathrm{~kg}$ basalt $\mathrm{m}^{-2}$ (Fig. $5 \mathrm{~b}$ and $\mathrm{d}$ ) in areas of high $\mathrm{P}$ deficiency ( $\sim 17$ and $\sim 7 \mathrm{~g} \mathrm{P} \mathrm{m}^{-2}$; Fig. 5a and c, respectively), considering the AR time span, the deployment rates would be less than $1 \mathrm{~kg}$ basal $\mathrm{m}^{-2} \mathrm{a}^{-1}$ if full congruent dissolution occurs as assumed for further given scenarios.

The total amount of basalt powder to close the estimated $\mathrm{P}$ gaps seen in Fig. 5 would depend on the assumed geogenic $\mathrm{P}$ supply scenario and chemical composition of wood and leaves, but for a mean $\mathrm{P}$ chemical composition, at least $\sim 153 \mathrm{Gt}$ basalt would be necessary for geogenic
$\mathrm{P}$ supply scenario one and $\sim 20 \mathrm{Gt}$ basalt for geogenic $\mathrm{P}$ supply scenario two. Basalt has a carbon capture potential of $\sim 0.3 \mathrm{tCO}_{2} \mathrm{t}^{-1}$ basalt (Renforth, 2012), resulting in $\sim$ $46 \mathrm{GtCO}_{2}(\sim 12.4 \mathrm{Gt} \mathrm{C})$ and $6 \mathrm{GtCO}_{2}(1.6 \mathrm{Gt} \mathrm{C})$ capture by closing the $\mathrm{P}$ gaps from Fig. 5a and c, respectively. If wood and leaves $\mathrm{P}$ concentration corresponds to 5 th percentiles (Table 1), 2 Gt basalt would be needed for closing the $\mathrm{P}$ gaps from a geogenic P supply scenario two (Fig. S1), which would potentially sequester $\sim 0.6 \mathrm{Gt} \mathrm{CO}_{2}(\sim 0.2 \mathrm{GtC})$ due to weathering. If wood and leaves $\mathrm{P}$ concentration corresponds to 95th percentiles (Table 1), 362 Gt basalt for closing the $\mathrm{P}$ gaps from a geogenic $\mathrm{P}$ supply scenario one (Fig. S3) would be necessary, which would potentially sequester $\sim 98 \mathrm{GtCO}_{2}(\sim 27 \mathrm{GtC})$ due to weathering. The amount of basalt needed was estimated for a $\mathrm{P}$ content of $500 \mathrm{ppm}$, and an increase in basalt $\mathrm{P}$ concentrations would represent a decrease in the necessary amounts of basalt powder. The incongruent dissolution of basalt might occur, 


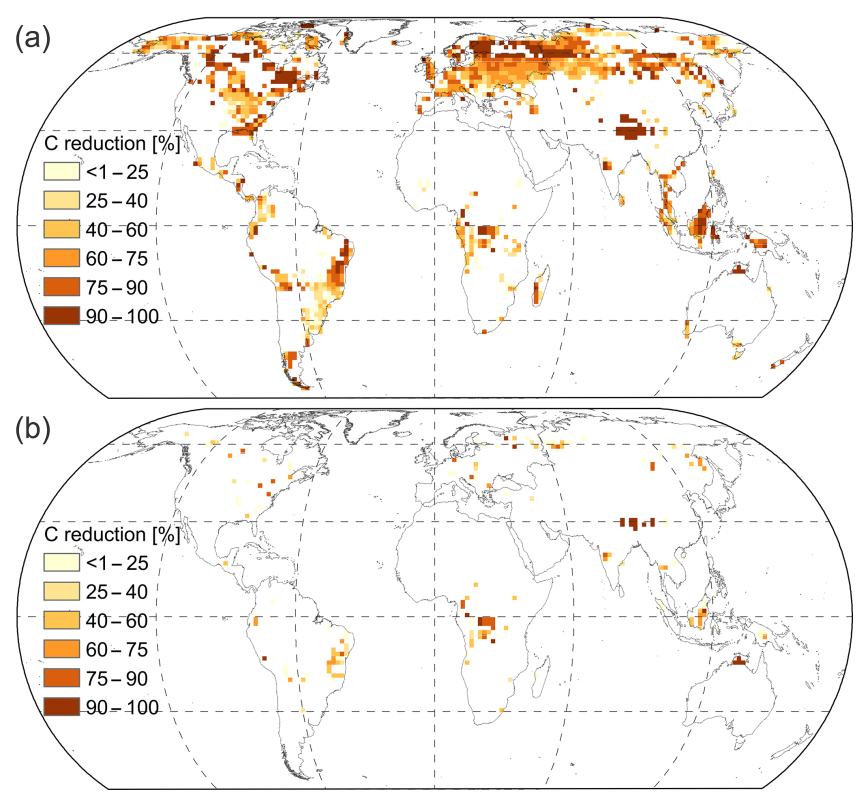

Figure 6. Reduction of forest $\mathrm{C}$ sequestration due to geogenic $\mathrm{P}$ limitation. $\mathrm{C}$ reduction estimated from stoichiometric $\mathrm{C}: \mathrm{P}$ ratios for the N-limited AR scenario assuming P concentrations within foliar and wood material corresponding to mean values (Table 1). In Fig. 2b we present the $\mathrm{C}$ sequestration potential if geogenic $\mathrm{P}$ supply is not limiting biomass growth. (a) $\mathrm{C}$ reduction based on $\mathrm{P}$ gaps in Fig. 5a, obtained for geogenic $\mathrm{P}$ supply scenario one (geogenic $\mathrm{P}$ from weathering plus atmospheric $\mathrm{P}$ deposition as source of $\mathrm{P}$ ). (b) $\mathrm{C}$ reduction based on $\mathrm{P}$ gaps of Fig. 5c, obtained for geogenic $\mathrm{P}$ supply scenario two (geogenic $\mathrm{P}$ from soil inorganic labile $\mathrm{P}$ and organic $\mathrm{P}$ pools plus atmospheric $\mathrm{P}$ deposition and $\mathrm{P}$ from weathering as source of $\mathrm{P})$. For resulting global $\mathrm{C}$ reduction check Table 3. (c) ESRI.

consequently increasing the necessary amounts of deployed basalt to cover the estimated $\mathrm{P}$ gaps.

Basalt deployment can also guarantee a balanced supply of $\mathrm{Mg}, \mathrm{Ca}$, and $\mathrm{K}$ for different deployment rates (Fig. 7), potentially preventing the shift of growth limitation to some of these nutrients within the P gapped areas (Fig. 5). Rhyolite, dacite, or andesite could be used as alternatives to basalt as a source of $\mathrm{P}$, but these rocks generally have lower $\mathrm{P}$ content (Fig. 4). As a consequence, the necessary amount of rhyolite, dacite, or andesite would be higher than that of basalt. Even though, for a median rock nutrient content, if these rocks are used to close the projected $\mathrm{P}$ gaps, they can potentially supply the necessary amount of $\mathrm{Ca}, \mathrm{Mg}$, and $\mathrm{K}$ for balanced tree nutrition (Fig. 8).

\subsection{Enhanced weathering coupled to bioenergy grass production}

For the simulation time span of 1995-2090 the minimum and maximum biomass growth yields amount to 0.7 and $3.6 \mathrm{~kg} \mathrm{~m}^{-2} \mathrm{a}^{-1}$, which represent a K export of $4.2-22 \mathrm{~g} \mathrm{~m}^{-2}$ and a P export of $0.7-3.6 \mathrm{~g} \mathrm{~m}^{-2}$ according to Eq. (2). To guar-
Table 4. Minimum and maximum soil hydraulic conductivity for areas coincident with the $\mathrm{P}$ gap areas of each geogenic $\mathrm{P}$ supply scenario, for the N-unlimited AR scenario (Fig. S7a).

\begin{tabular}{lrr}
\hline & $\begin{array}{r}\text { Geogenic P supply } \\
\text { scenario one }\end{array}$ & $\begin{array}{r}\text { Geogenic P supply } \\
\text { scenario two }\end{array}$ \\
\hline \multicolumn{2}{l}{ Hydraulic conductivity $\left(\mathrm{K} ; \mathrm{m} \mathrm{s}^{-1}\right)$} \\
\hline Min & $1.5 \times 10^{-7}$ & $2.7 \times 10^{-7}$ \\
Max & $1.7 \times 10^{-4}$ & $7.8 \times 10^{-5}$ \\
\hline Plant-available water (PAW; \%) & \\
\hline Min & 4 & 6 \\
Max & 32 & 28 \\
\hline
\end{tabular}

antee maximum bioenergy grass yield, the exported nutrients should be replaced. For a high nutrient content (95th percentile), deploying up to $1.5 \mathrm{~kg}$ basalt m $\mathrm{m}^{-2} \mathrm{a}^{-1}$ could meet the $\mathrm{K}$ needs of bioenergy grass (Fig. 9) and would be able to replenish up to $75 \%$ of the exported $\mathrm{P}$ if the maximum bioenergy grass yield is considered (Fig. 9). Industrial fertilizer coapplication would be indicated to completely replenish exported $\mathrm{P}$, reducing industrial fertilizer dependency. Deploying $8 \mathrm{~kg}_{\text {basalt }} \mathrm{m}^{-2} \mathrm{a}^{-1}$ would be enough to replenish exported $\mathrm{K}$ and $\mathrm{P}$ by harvest, assuming median nutrient content of basalt powder and congruent and complete dissolution (Fig. 9).

\subsection{Impacts on soil hydrology}

The baseline hydraulic properties for soils within the $\mathrm{P}$ gap areas from the $\mathrm{N}$-unlimited AR scenario, since this scenario represents the maximum effect, were estimated by Eq. (10), and they show high variability. The projected hydraulic conductivity $\left(K_{\mathrm{S}}\right)$ of topsoils for areas corresponding to those of the $\mathrm{P}$ budget from geogenic $\mathrm{P}$ supply scenario one (Fig. S7a), for the $\mathrm{N}$-unlimited AR scenario, encompasses values ranging from $1.5 \times 10^{-7}$ to $7.8 \times 10^{-5} \mathrm{~m} \mathrm{~s}^{-1}$ and with PAW of $4 \%$ and $32 \%$ (Table 4). Neglecting the topography, soils having low $K_{\mathrm{S}}$, (e.g., values of $1.5 \times 10^{-7} \mathrm{~m} \mathrm{~s}^{-1}$ ) would experience the lowest water infiltration rate. The impacts of deploying a fine basalt texture $(15.6 \%$ clay, $83.8 \%$ silt, and $0.6 \%$ fine sand) or a coarse basalt texture ( $15.6 \%$ clay, $53.8 \%$ silt, and $30.6 \%$ fine sand), which are in the range of commercial powders (Nunes et al., 2014), on soil hydrology were estimated by Eq. (10) for different application upper limits.

The effects of rock powder deployment could be neglected, on average, for upper limits of 50 and $205 \mathrm{~kg}_{\text {basalt }} \mathrm{m}^{-2}$ for a fine- and coarse-textured rock powder, respectively. However, deviations from what is expected for the mean might occur (Figs. 10 and 11). The average values of PAW increase together with the increase in the upper limits of rock powder application, but for a coarse basalt 

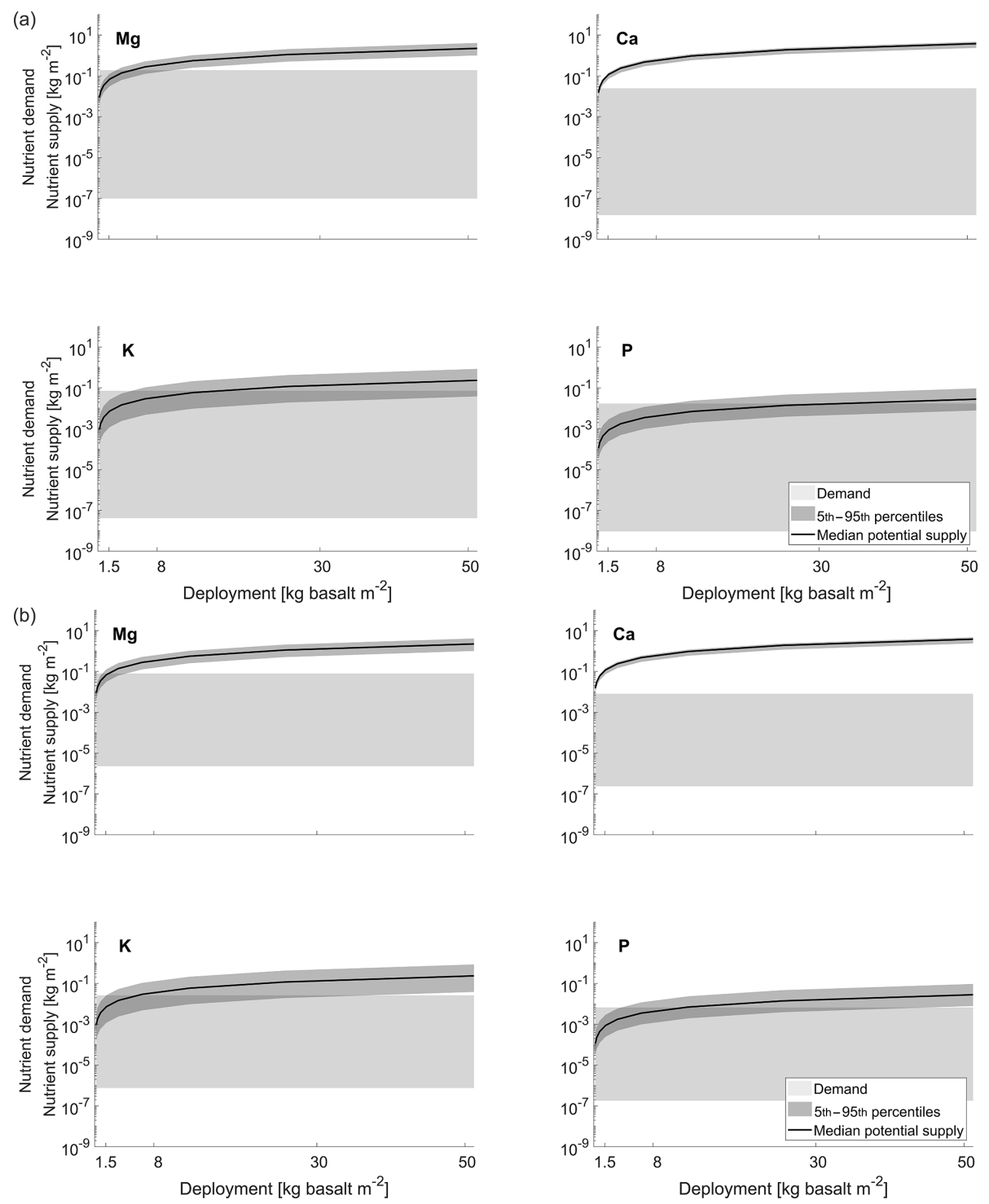

Figure 7. $\mathrm{Mg}, \mathrm{Ca}, \mathrm{K}$, and $\mathrm{P}$ supply by basalt dissolution (logarithmic curve) given as medians and ranges (5th and 95th percentiles; dark grey areas). Horizontal filled boxes indicate the nutrient demand for the maximum $\left(17.1 \mathrm{~g} \mathrm{P} \mathrm{m}^{-2}\right)$ and minimum $\left(\ll 1 \mathrm{~g} \mathrm{P} \mathrm{m}{ }^{-2}\right)$ gap of each geogenic $\mathrm{P}$ supply scenario for $\mathrm{P}$ and derived $\mathrm{Mg}, \mathrm{Ca}$, and $\mathrm{K}$ demand for balanced tree nutrition assuming mean foliar and wood material chemistry (Table 1). (a) Based on minimum and maximum $\mathrm{P}$ gap values of $<1$ and $16.6 \mathrm{~g} \mathrm{P} \mathrm{m}^{-2}$, which were obtained for a geogenic $\mathrm{P}$ supply scenario one (geogenic $\mathrm{P}$ from weathering plus atmospheric $\mathrm{P}$ deposition as source of $\mathrm{P}$ ). (b) Based on minimum and maximum $\mathrm{P}$ gap values of $<1$ and $6.7 \mathrm{~g} \mathrm{P} \mathrm{m}^{-2}$, which were obtained for a geogenic $\mathrm{P}$ supply scenario two (geogenic $\mathrm{P}$ from soil inorganic labile $\mathrm{P}$ and organic $\mathrm{P}$ pools plus atmospheric $\mathrm{P}$ deposition and $\mathrm{P}$ from weathering as source of $\mathrm{P}$ ).

powder some areas might experience a decrease in PAW (Figs. 10 and 11).

Closing the observed $\mathrm{P}$ gap areas in the $\mathrm{N}$-unlimited AR scenario would require a maximum deployment of $34 \mathrm{~kg}$ basalt $\mathrm{m}^{-2}$ if geogenic $\mathrm{P}$ supply scenario one is assumed and $13 \mathrm{~kg}$ basalt $\mathrm{m}^{-2}$ if geogenic $\mathrm{P}$ supply scenario two is assumed (Fig. S7). Filling the $\mathrm{P}$ gaps from scenario two by a coarse or fine basalt powder (given the complete dissolution of P-bearing minerals), the related changes in soil hydrology would remain below $\pm 10 \%$ for most of the areas
(Fig. S12). If the geogenic P supply from scenario one, for the N-unlimited AR scenario (Fig. S7a), is assumed and a fine basalt powder is applied, the changes in hydraulic conductivity range between $58 \%$ and $-11 \%$ (Fig. 12a). A decrease in PAW could be neglected for most of the deployment areas, but some would have an increase of up to $31 \%$ from $13.8 \%$ to $18.2 \%$ (Fig. 12c). A coarse basalt powder would, in general, cause fewer impacts to soil hydraulic properties (Fig. 12b and d). 


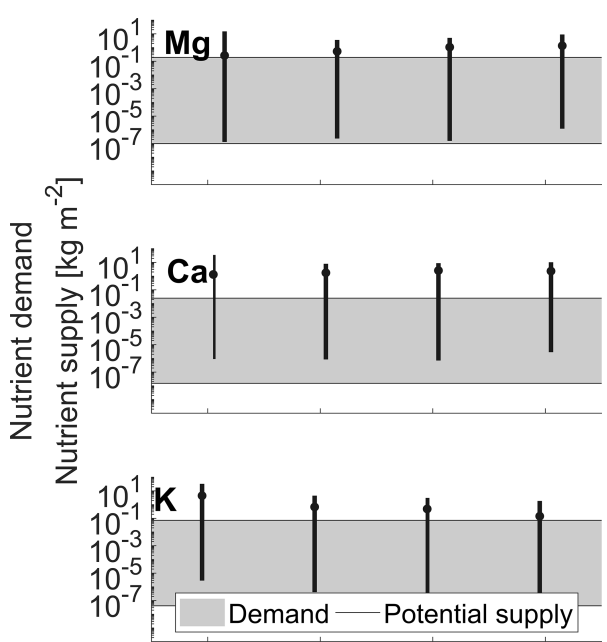

Rhyolite Dacite Andesite Basalt

Figure 8. Potential macronutrient $(\mathrm{Mg}, \mathrm{Ca}$, and $\mathrm{K})$ supply of different rocks for closing projected $\mathrm{P}$ gaps of $\ll 1$ to $17.1 \mathrm{~g} \mathrm{P} \mathrm{m}^{-2}$. Medians and ranges (5th and 95th percentiles) of potential supply based on rock chemistry.

\section{Discussion and implications}

\subsection{Enhanced weathering coupled to afforestation and reforestation}

Phosphorus $(\mathrm{P})$ is a limiting nutrient in a wide range of ecosystems (Elser et al., 2007) and in temperate and tropical climate zones (Du et al., 2020). P deficiency might affect biomass growth of tropical (Herbert and Fownes, 1995; Tanner et al., 1998; Wright et al., 2011) and northern forests (Menge et al., 2012; Goswami et al., 2018) with mineral $\mathrm{P}$ already limiting biomass production in European forests (Jonard et al., 2015) and in forests in the USA (Garcia et al., 2018), as well as in agricultural areas (Ringeval et al., 2019; Kvakić et al., 2018). The uncertainty in which the $\mathrm{P}$ pool is available for long-term plant nutrition is high (Johnson et al., 2003; Sun et al., 2017), and we tackled this uncertainty assuming two potential geogenic P supply scenarios. Geogenic supply scenario two, assuming $\mathrm{P}$ from weathering and atmospheric deposition plus inorganic labile $\mathrm{P}$ and organic $\mathrm{P}$, is a very optimistic assumption that might not correspond to reality based on the already-observed $\mathrm{P}$ limitation on different ecosystems (Elser et al., 2007). However, we cannot rule out that gradual shifts in soil organic $\mathrm{P}$ fractions occur, which make comparable amounts of $\mathrm{P}$ to that available in scenario two over time.

The numerical simulations of Kracher (2017) predicted biomass growth for the 21st century (Fig. 2) considering natural water supply, $\mathrm{CO}_{2}$ fertilization, and $\mathrm{N}$-unlimited and N-limited scenarios for an RCP4.5 greenhouse gas concentration trajectory and land use transitions. The predicted $\mathrm{C}$ sequestration by the $\mathrm{N}$-limited AR scenarios from
Kracher (2017) is $\sim 2 \mathrm{GtCa}^{-1}$. Different authors have reported the potential $\mathrm{C}$ sequestration by afforestation or reforestation being of $0.3-3.3 \mathrm{Gt} \mathrm{Ca}^{-1}$ for the end of 2099 (National Research Council, 2015; Lenton, 2014, 2010; Smith et al., 2015; Fuss et al., 2018). However, the predicted sequestration potential estimated by Kracher (2017) can drop to $\sim 1.3 \mathrm{Gt} \mathrm{Ca}^{-1}$ if geogenic $\mathrm{P}$ supply scenario one for mean $\mathrm{P}$ content within wood and leaves is selected. If geogenic $\mathrm{P}$ supply scenario two for mean $\mathrm{P}$ content within wood and leaves is selected, it drops to $\sim 1.9 \mathrm{Gt} \mathrm{Ca}^{-1}$.

More than 60000 tree species are recorded worldwide (Beech et al., 2017), and a precise estimation regarding tree chemistry, which we attempted to represent by the considered ranges of wood and leaves chemistry from the databases, represents a challenge. However, different pathways and mechanisms control soil $\mathrm{P}$ availability to the plant (Vitousek et al., 2010), and they are not considered in our estimations, leading to conservative predictions. Adding soil $\mathrm{P}$ dynamics to models would allow for the reliable quantification of the $\mathrm{C}$ sequestration potential of AR (e.g., using Penabled land surface models; Sun et al., 2017; Wang et al., 2010, 2017; Goll et al., 2012, 2017; Yang et al., 2014b).

Kracher (2017) has shown that N can limit biomass production and consequently $\mathrm{C}$ sequestration. To achieve the projected C sequestration of $190 \mathrm{Gt} C$ for the N-limited scenario, the estimated $\mathrm{P}$ gaps must be closed. Potential $\mathrm{P}$ sources are industrial fertilizers, like diammonium phosphate (DAP) or rock powder (e.g., basalt). However, DAP potentially represents an extra input of ammonium to the groundwater, and it is expected, in the long term, that DAP deployment will acidify the soil (Fertilizer Technology Research Centre, 2016).

Most of the world's soils are acidic, with some being strongly acidic (IGBP-DIS, 1998), which generally favors the sorption of orthophosphate onto Fe- and Al-(hydro)oxide surfaces and clay minerals, essentially demobilizing P (Shen et al., 2011). Besides that, the long AR time span can undermine the effectiveness of DAP to supply P to forests due to the high soil acidification potential of DAP. Therefore, rock powder application can be an alternative as nutrients are slowly released and an increase in alkalinity fluxes is expected (Dietzen et al., 2018), which can raise and stabilize the $\mathrm{pH}$ of soils.

Re-establishing soil $\mathrm{pH}$ to (near-)neutral conditions, generally between 6.6 and 7, will provide new nutrient-holding sites at Fe- and Al-(hydro)oxide surfaces and in soil organic matter, which makes the sorbed orthophosphate plant available. An application of $8 \mathrm{~kg} \mathrm{~m}^{-2}$ basalt powder can increase the cation exchange capacity (CEC) of Oxisols by $150 \%-$ $300 \%$ (Anda et al., 2015, 2009) and improve the $\mathrm{C}$ and $\mathrm{N}$ mineralization (Mersi et al., 1992); for Ultisols, the CEC increases by $44 \%$ after deploying $\sim 7 \mathrm{~kg} \mathrm{~m}^{-2}$ basalt powder (Noordin et al., 2017).

To avoid shifts of nutrient limitation, the supply of macronutrients like $\mathrm{Mg}, \mathrm{Ca}$, and $\mathrm{K}$ might be proportional to $\mathrm{P}$ 

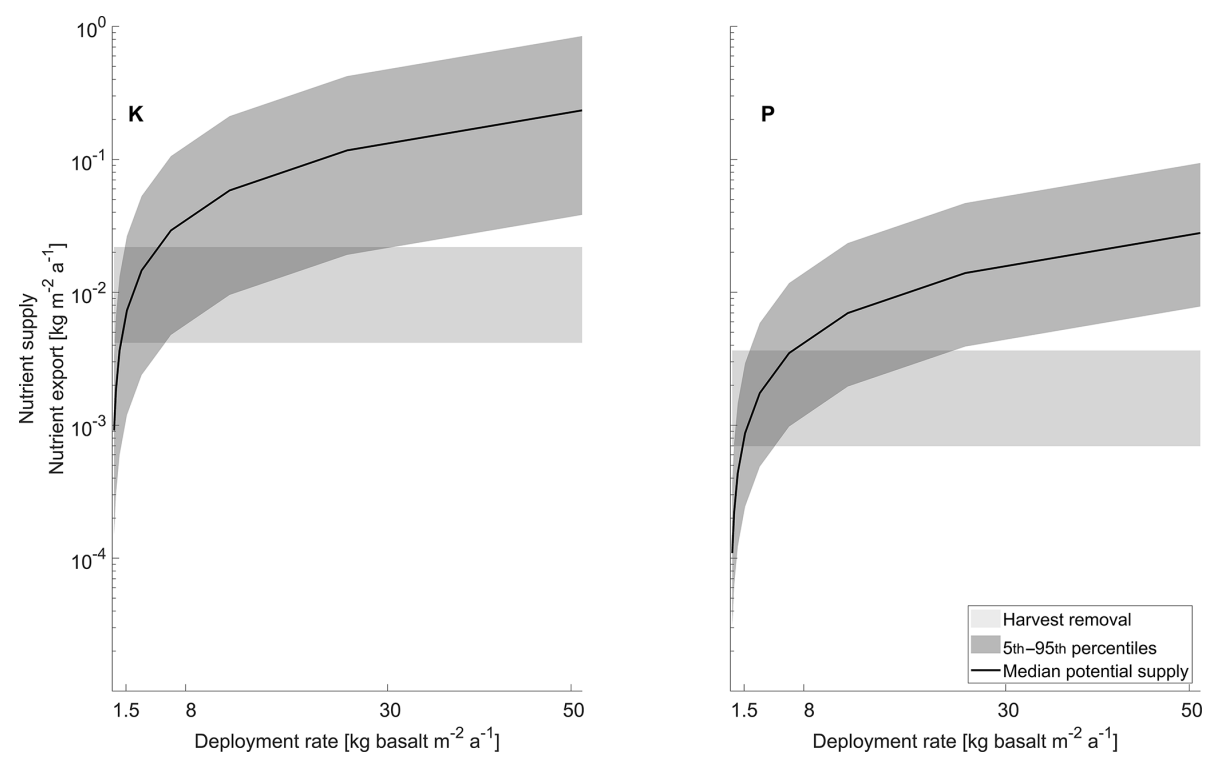

Figure 9. Projected K and P supply (logarithmic curve) by basalt dissolution given as median ranges (5th and 95th percentiles) for bioenergy grasses $\mathrm{K}$ and $\mathrm{P}$ demand (horizontal filled boxes) based on global minimum 0.7 and maximum $3.6 \mathrm{~kg} \mathrm{~m}^{-2} \mathrm{a}^{-1}$ harvest rates for simulation years of 1995-2090. The number of exported nutrients by several harvest rates higher than the minimum and lower than the maximum harvest rates are represented by the horizontal filled boxes.

supply since $\mathrm{Mg}$ is required as an essential element in chlorophyll, Ca has a structural role, and $\mathrm{K}$ is responsible for water and ionic balance (Hopkins and Hüner, 2008). Rock powder can be used as a source of these nutrients, as suggested by different authors (Beerling et al., 2018; Hartmann et al., 2013; Straaten, 2007) and according to our results seen in Figs. 7 and 8. However, the potential of basalt powder to supply K, based on chemical composition, is lower than for other analyzed rocks. For median values, rhyolite has the highest content of $\mathrm{K}$; however, if occurring in $\mathrm{K}$-feldspars it will not be plant available. Blending these rocks in different proportions could result in a more balanced macronutrient supply (Leonardos et al., 1987).

The RCP8.5 scenario predicts that global agricultural areas (crop land and pastures) are going to increase in the course of the 21st century due to a decrease in forested area (Sonntag et al., 2016). Assuming a future scenario of high atmospheric $\mathrm{CO}_{2}$ levels (RCP8.5) but using the land use transitions and wood harvest rates from an RCP4.5 scenario (Sonntag et al., 2016), a similar forest cover fraction to the one presented in Fig. 2 is expected (see Fig. 1 in Sonntag et al., 2016), and geogenic P supply would also limit the predicted biomass growth. Similar areas of forest growth were observed in the study from Yousefpour et al. (2019) by comparing Fig. 2c presented in that study and Fig. 2 in our study. Though using only one model induces uncertainty, it would not change the general message of our work.

\subsection{Enhanced weathering coupled to bioenergy grass production}

Generally, natural soil P content is inadequate for the longterm cultivation of agricultural plants. To overcome this issue, $\mathrm{P}$ is supplied by fertilizers to reach or maintain optimum levels of crop productivity (Sharpley, 2000) after several harvest rotations. In order to keep a positive $\mathrm{CO}_{2}$ balance, an alternative to industrial fertilizers might be used to replenish the nutrients exported by harvest. The chemical composition of rocks is highly variable (Fig. 4), and different rock types can be used for EW. Ideal rock types need to be chosen in order to resolve a specific plant nutrient deficiency and enhance the nutrient reservoir of a target soil, besides increasing the soil pH and the CEC (Anda et al., 2015, 2009) and improving the $\mathrm{C}$ and $\mathrm{N}$ mineralization (Mersi et al., 1992), the soil organic carbon (Doetterl et al., 2018), and the supply of Si (Beerling et al., 2018; Hartmann et al., 2013). In the case of Oxisols, which are also found over about $8 \%$ of the glacierfree land surface and common in tropical and subtropical agricultural regions, application of $8 \mathrm{~kg} \mathrm{~m}^{-2}$ basalt powder can increase the CEC by $150 \%-300 \%$ (Anda et al., 2015, 2009). For Ultisols, which are found over about $8 \%$ of the glacier-free land surface, application of $\sim 7 \mathrm{~kg} \mathrm{~m}^{-2}$ basalt powder can increase the CEC by $44 \%$ (Noordin et al., 2017).

Overall, rock application has the potential to resupply the harvest-exported nutrients and partially or totally close the short- and long-term nutrient gaps in soil. Individual rock types, from basic $(\mathrm{Mg}, \mathrm{Ca})$ to acidic $(\mathrm{K}, \mathrm{Na})$, contain varying amounts of target nutrients, and mixing them might increase 

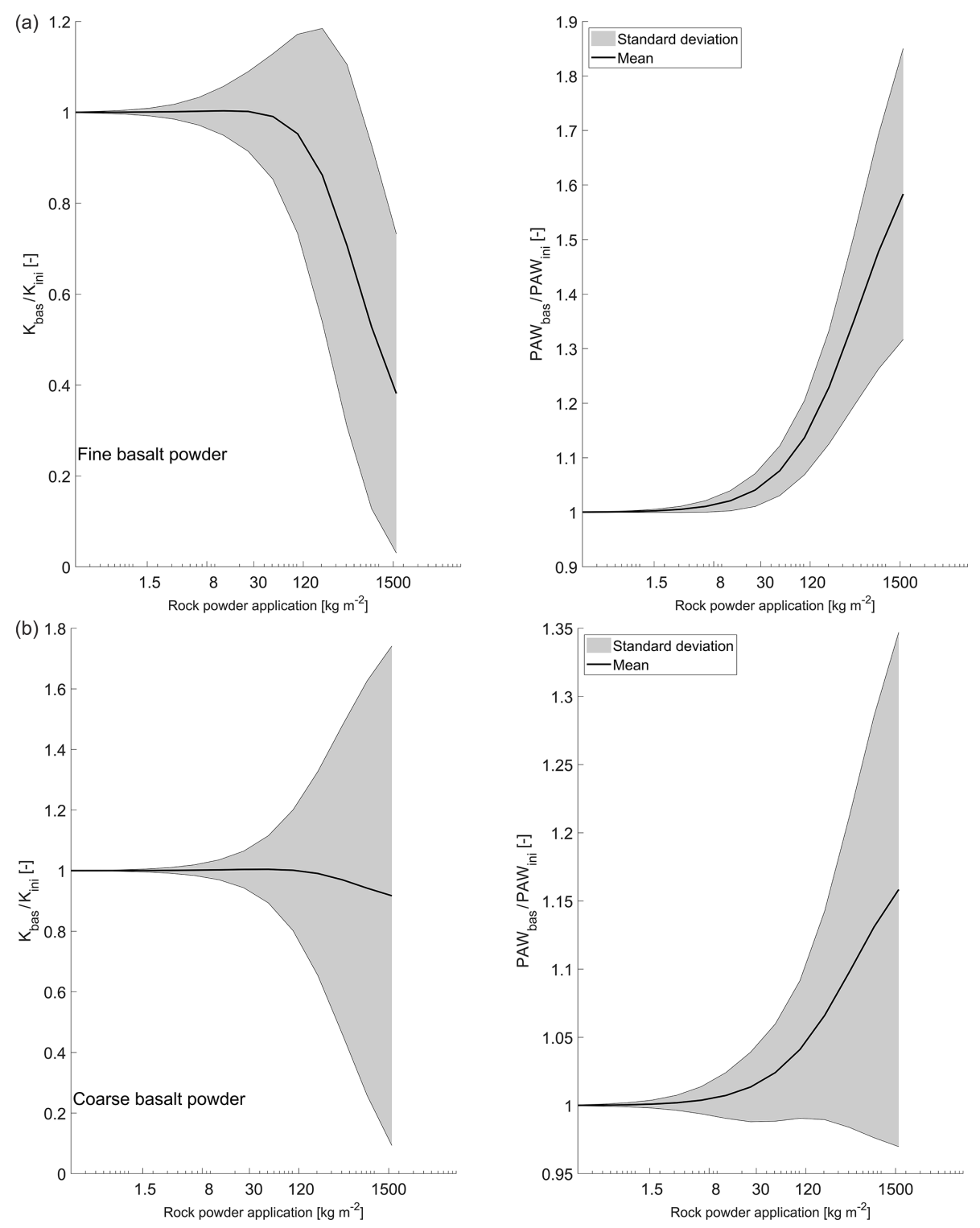

Figure 10. Relative impacts on soil saturated hydraulic conductivity $\left(K_{\mathrm{S}}\right)$ and plant-available water (PAW). $\mathrm{K}_{\text {bas }}$ and PAW bas, respectively, represent the estimated soil $K_{\mathrm{S}}$ and PAW after basalt application. $\mathrm{K}_{\mathrm{ini}}$ is the estimated initial soil $K_{\mathrm{S}}$, and PAW ini is the estimated initial PAW of different soils. (a) Application of a fine basalt texture (15.6\% clay, $83.8 \%$ silt, and $0.6 \%$ fine sand). (b) Application of a coarse basalt texture ( $15.6 \%$ clay, $53.8 \%$ silt, and $30.6 \%$ fine sand) for areas corresponding to $\mathrm{P}$ gaps of geogenic P supply scenario one, for the N-unlimited AR scenario (Fig. S7a). Mean and standard deviations for $n=15318$ grid cells. See Sect. D in the Supplement for impacts of initial $K_{\mathrm{S}}$ and PAW of fine or coarse basalt powder texture on soils of P gap areas from Fig. S7c.

the overall nutrient supply capacity (Leonardos et al., 1987). Intrinsic mineralogical and/or petrographic structures can influence the release of nutrients (Ciceri et al., 2017), which makes them plant unavailable in some cases. $\mathrm{K}$ can also limit plant growth; it occurs in K-feldspars as a plant-unavailable form, in the case of acidic rocks, but becomes accessible after hydrothermal treatment (Liu et al., 2015; Ma et al., 2016a, b). However, research on release processes of other macro- and micronutrients and on nutrient release optimization (e.g., by hydrothermal decomposition) is necessary to be able to parameterize this effect in the soil environment.

Harvest rates control the nutrient export from bioenergy grass fields. Therefore, an increase in harvest rate represents an increase in nutrient export and vice versa. Thus, to keep a sustainable nutritional balance of soils, the exported nutrients must be replenished; otherwise maintaining the high harvest rates becomes unsustainable. Accounting for other simulation setups or a numerical model different from MAgPIE might change the harvest rates of this study. If we as- 

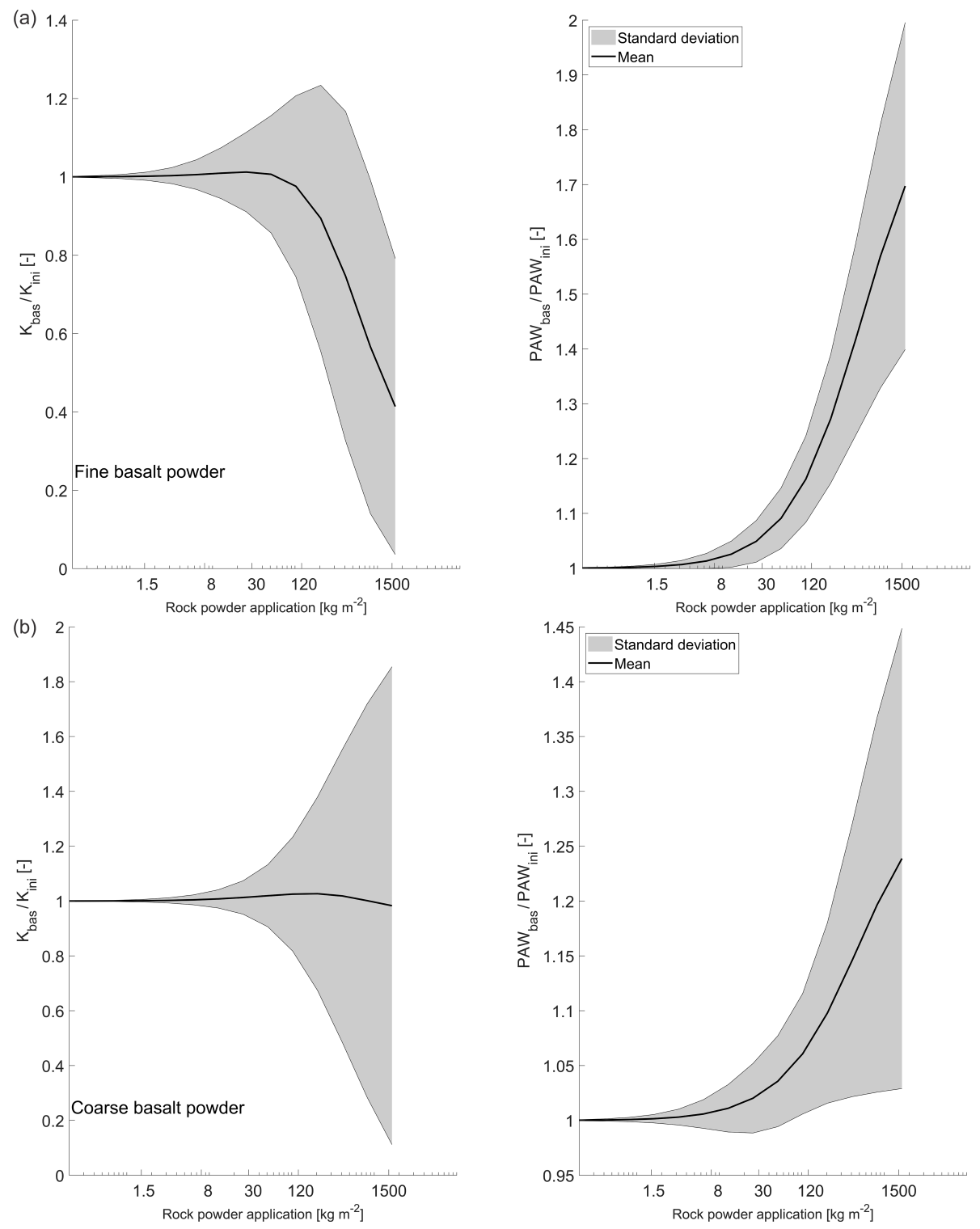

Figure 11. Relative impacts on soil saturated hydraulic conductivity $\left(K_{\mathrm{S}}\right)$ and plant-available water (PAW). $K_{\text {bas }}$ and PAW bas , respectively, represent the estimated soil $K_{\mathrm{S}}$ and PAW after basalt application. $\mathrm{K}_{\mathrm{ini}}$ is the estimated initial soil $K_{\mathrm{S}}$, and PAW ini is the estimated initial PAW of different soils. (a) Application of a fine basalt texture (15.6\% clay, $83.8 \%$ silt, and $0.6 \%$ fine sand). (b) Application of a coarse basalt texture ( $15.6 \%$ clay, $53.8 \%$ silt, and $30.6 \%$ fine sand) for areas corresponding to P budget scenario two, for the N-unlimited AR scenario (Fig. S7c). Mean and standard deviations for $n=2525$ grid cells.

sume that the maximum harvest rate of $3.6 \mathrm{~kg} \mathrm{~m}^{-2} \mathrm{a}^{-1}$ hypothetically increases by 1 order of magnitude, the maximum exported nutrients would be $\sim 0.2 \mathrm{~kg} \mathrm{~K} \mathrm{~m}^{-2} \mathrm{a}^{-1}$ and $\sim 0.04 \mathrm{~kg} \mathrm{P} \mathrm{m}^{-2} \mathrm{a}^{-1}$, which would demand a basalt deployment rate of $\sim 13$ and $\sim 20 \mathrm{~kg} \mathrm{~m}^{-2} \mathrm{a}^{-1}$, respectively (considering the 95th percentiles of the chemical composition of basalt), to replenish the exported nutrients. If median $\mathrm{K}$ and $\mathrm{P}$ concentrations in basalt powder are assumed, the basalt deployment rate increases to $\sim 48$ and $73 \mathrm{~kg} \mathrm{~m}^{-2} \mathrm{a}^{-1}$, respectively, to replenish the exported nutrients (Fig. S11). However, such an increase in harvest rates might not correspond to reality. Harvest rates lower than $0.7 \mathrm{~kg} \mathrm{~m}^{-2} \mathrm{a}^{-1}$ (the minimum) represent less nutrient export, decreasing the basalt powder deployment rates necessary to replenish the nutrients exported by harvest.

\subsection{Impacts on soil hydrology}

$\mathrm{AR}$ and BECCS demand huge quantities of irrigation water (Boysen et al., 2017b; Bonsch et al., 2016), and it is projected that climate change will affect the water balance and consequently influence crop yields (Kang et al., 2009). Soils 
(a)

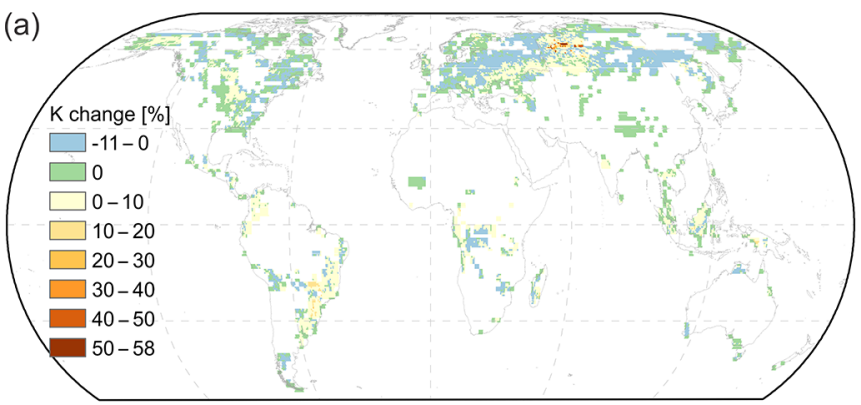

(c)

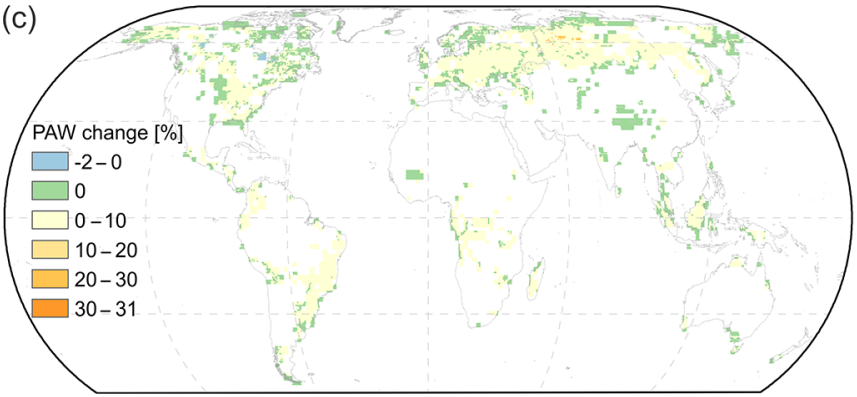

(b)

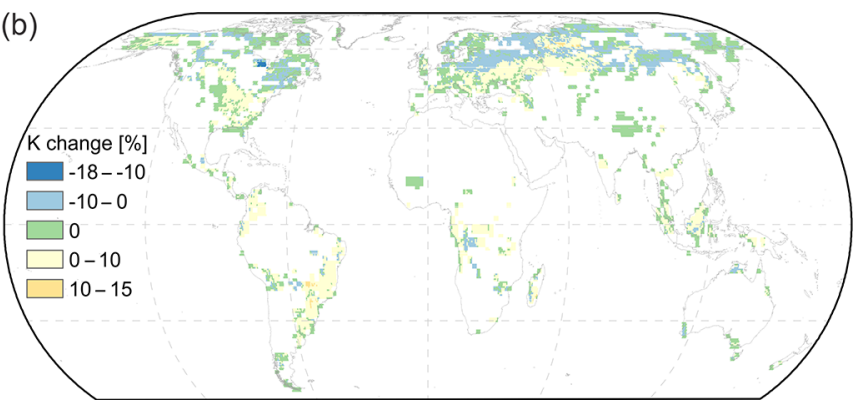

(d)

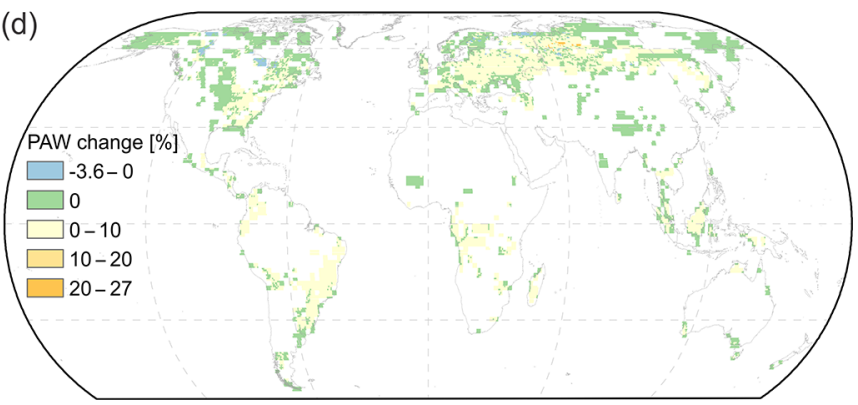

Figure 12. Impacts on soil hydrology estimated according to the equations of Saxton and Rawls (2006) for basalt deployment mass coincident with areas with potential P gaps for the nutrient budget of the N-unlimited AR scenario assuming P concentrations within foliar and wood material corresponding to mean values (Fig. S7a). (a) Hydraulic conductivity (K) changes relative to initial soil values for a fine basalt texture ( $15.6 \%$ clay, $83.8 \%$ silt, and $0.6 \%$ sand) being deployed. (b) Hydraulic conductivity (K) changes relative to initial soil values for a coarse basalt texture (15.6\% clay, $53.8 \%$ silt, and $30.6 \%$ fine sand) being deployed. (c) Plant-available water (PAW) changes relative to initial soil values for a fine basalt texture ( $15.6 \%$ clay, $83.8 \%$ silt, and $0.6 \%$ sand) being deployed. (d) Plant-available water (PAW) changes relative to initial soil values for a coarse basalt texture ( $15.6 \%$ clay, $53.8 \%$ silt, and $30.6 \%$ fine sand) being deployed. () ESRI.

with higher water-holding capacity will tolerate the impacts of drought better (Kang et al., 2009). Therefore, practices that improve water availability to plants at the root system are used as strategies to mitigate drought effects (Rossato et al., 2017). We investigated whether deployment of rock powder can change the topsoil hydraulic conductivity and plantavailable water (PAW) for different application ranges.

Concrete effects of EW on biomass productivity would depend on whether the changes in the initial PAW values in topsoils reached PAW threshold values to trigger biomass productivity (Sadras and Milroy, 1996). In general, the average changes in topsoil PAW related to basalt powder application would not be enough to trigger biomass growth. Therefore, areas showing PAW changes from $14 \%$ to $21 \%$ would not trigger leaf and stem expansion of maize, wheat, or soybean (Sadras and Milroy, 1996) but could increase leaf and stem expansion of pearl millet (Sadras and Milroy, 1996) after deploying $50 \mathrm{~kg}_{\text {basalt }} \mathrm{m}^{-2}$ with a fine texture. A deployment of $50 \mathrm{~kg}$ basalt $\mathrm{m}^{-2}$ of coarse powder changes PAW by $19 \%$, consequently not triggering biomass productivity.

The finest grain size able to be considered in the equations of Saxton and Rawls (2006) is the clay fraction (grain diameter $>1$ and $<3.9 \mu \mathrm{m}$ ). Fine grain sizes influence the exposed reactive surface area of rock powder, which affect the weathering rates. The fine basalt would have the grain sizes ranging between 0.6 and $90 \mu \mathrm{m}$ which might be enough to completely dissolve the deployed rock powder after 1 a (Strefler et al., 2018). For the coarse basalt powder, $\sim 70 \%$ of its granulometry falls into the $0.6-90 \mu \mathrm{m}$ range, and from the other $30 \%$, about $20 \%$ might be dissolved in 1 a (Strefler et al., 2018). Based on the used pedotransfer functions, if a basalt powder contained only grains of the clay size fraction, the effects on soil hydraulic conductivity would decrease by $37 \%$ for a deployment amount of $30 \mathrm{~kg}_{\text {basalt }} \mathrm{m}^{-2}$ (for the fine rock powder used in our work, the hydraulic conductivity would decrease by only $2 \%$ ). The finer the grain becomes, the higher the energy input for grinding is, which can drastically affect the costs of EW (it can reach up to USD $500 t \mathrm{CO}_{2}^{-1}$ sequestered; Strefler et al., 2018). Since grains of different diameters need different times for complete dissolution, a rock powder with different grain sizes would act as a constant source of nutrients to soil.

During the weathering of rock powder, clay mineral genesis can occur and potentially increase the water-holding capacity of soils (Gaiser et al., 2000), which can subsequently change the estimated PAW. The added fresh silicate minerals to the soil by EW will have high reactivity releasing a significant number of nutrients, which increases soil nutrient pools. The increased nutrient availability will increase the potential of soils to stabilize carbon (Doetterl et al., 2018), and a positive effect on PAW is expected to occur based on Eqs. (1517) and according to Olness and Archer (2005). The suit- 
able amounts of rock powder applied depend on the target changes in the chosen soil and on the soil's intrinsic grain size distribution and organic matter content. Intrinsic grain properties like the shape of grains and pores, tortuosity, specific surface area, and porosity should be considered (Bear, 1972) for the evaluation of changes in soil hydraulic properties by pedotransfer functions and their consequences for dissolution kinetics. A large set of data from field and laboratory experiments covering different soil types, climatic regions, and plant species would enable a qualitatively and quantitatively reliable assessment of not only soil hydrology impacts but also dissolution rates and changes in the soils' mineralogy. The effects on soil microorganisms should be taken into account in order to correct the limits of rock powder deployment. The potential of rock powder to trigger plant suffocation, if gas exchange is prevented by water saturation of pores (Sairam, 2011), should also be considered before deployment.

\subsection{Challenges of rock powder deployment}

Average tillage depth is $0.3 \mathrm{~m}$, and greater depths can be reached with higher energy and labor costs (Fageria and Baligar, 2008). Since annual crops have an effective rooting depth typically in the range of 0.4-0.7 m (Madsen, 1985; Aslyng, 1976; Munkholm et al., 2003; Olsen, 1958), a deployment depth of $0.3 \mathrm{~m}$ seems to be reasonable.

Since tillage can trigger soil carbon loss (Reicosky, 1997; La Scala et al., 2006), deploying rock powder at soil surface might be a solution. At the soil surface, the long-term water percolation and/or bioturbation (Fishkis et al., 2010; Taylor et al., 2015) can transport and mix fine-grained material to deeper regions within the soil profile, which potentially can change the $K_{\mathrm{S}}$ and PAW at crop rooting zones. Groundwater recharge rates might change if clogging of pores at deeper regions of the soil profile occurs or if the changes in soil hydraulic properties due to rock deployment can significantly influence the initial soil hydraulic conditions for a constant water precipitation. Taylor et al. (2015) argue that downward transport of a silt-textured powder deployed at a soil surface would easily reach the rooting zone of trees, which is in the majority of cases at a depth of up to $0.4 \mathrm{~m}$. The authors suggest that in tropical regions greater depths might be reached due to intensive rain and bioturbation.

Detailed field studies to better comprehend downward transport of grained material through the soil profile, changes in soil water residence time, PAW, mineralogy, nutrient pools, CEC (Anda et al., 2015, 2013), and bioavailability of released trace metals (Renforth et al., 2015) are necessary. This would provide management recommendations for the diverse existing settings for EW application. In the present study, estimates for different basalt powder application upper limits are made for changes in soil hydraulic properties without accounting for downward transport of fine particles through the soil profile.
Besides avoiding clogging of pores of the topsoil by rock powder application to a certain extent, downward transport of rock powder can contribute freshly ground material that comes into contact with roots of trees or crops, which can enhance the weathering rates and create new sites to retain nutrients (Kantola et al., 2017; Anda et al., 2015).

Once the freshly ground material is in contact with the soil, different factors control the nutrient supply efficiency of rock powder. The nutrients from fresh material are initially inert, protected within the crystallographic structures of the minerals, and would become plant available only in solution or when associated with mineral surfaces (Appelo and Postma, 2005). The release of nutrients by weathering is controlled by film and intraparticle diffusion-limited mass transfer influenced by $\mathrm{pH}$ and ionic strength of the soil aqueous solution (Grathwohl, 2014), both being controlled by rooting exudates in the rhizosphere and the chemical composition of infiltrating waters.

Full dissolution is a simplification based on modeled scenarios (Taylor et al., 2015; Strefler et al., 2018). Under field conditions, soil water could rapidly reach nearequilibrium concentrations (Grathwohl, 2014), which would decrease weathering rates. The opposite would occur if nearequilibrium conditions could be disturbed by a sink of nutrients by nutrient root uptake (Stefánsson et al., 2001) or by percolation of water unequilibrated with soil porous water (Calabrese et al., 2017).

The nutrient $(\mathrm{Mg}, \mathrm{Ca}, \mathrm{K}, \mathrm{P}$, etc.) content of rocks can vary significantly. Besides that, deploying rock powders with grain sizes $>90 \mu \mathrm{m}$ would decrease the reactive surface area of deployed rock powder, decreasing the weathering fluxes (Goddéris et al., 2006). The median and the range (5th or 95th percentile) values for $\mathrm{Mg}, \mathrm{Ca}, \mathrm{K}$, and $\mathrm{P}$ content obtained from the EarthChem database considered chemical analysis of 2985 rhyolites, 3008 dacites, 11099 andesites, and 23816 basalts. Broadening the classification criteria for these rocks would change the median and the ranges (5th or 95th percentile) for chemical composition; however, the selected median and the ranges of this study are conservative estimates. As an illustration, Porder and Ramachandran (2013) adopted another selection criterion for the same database, which resulted in a total of 97895 samples and estimated a median P content of basalt of $916 \mathrm{ppm}$. Additionally, the selected rock chemistry database influences the descriptive statistics results. Recently published values of $\mathrm{P}$ content within basalt considering the GEOROC database are $1309 \mathrm{ppm}$ for median content, $428 \mathrm{ppm}$ for the 10 th percentile, and $3186 \mathrm{ppm}$ for the 90th percentile (Amann and Hartmann, 2019). Thus, before deploying EW to supply nutrients, the chemical composition of rock powder should be known to properly estimate the necessary amount of rock for supplying the demanded nutrients of a specific plant. This would allow for the easy estimation of the impacts on soil hydrology by the pedotransfer functions of this study or by specific laboratory experiments. 
Besides the potential to be used to rejuvenate soil nutrient pools (Leonardos et al., 1987), silicate rock powder can be used to reduce the risk of nitrate mobilization and is indicated for regions in which special care regarding water preservation is needed. However, extra input of sodium $(\mathrm{Na})$ to the system, if the rock is rich in this element, could disturb this amelioration effect (Von Wilpert and Lukes, 2003). Besides decreasing nitrate mobilization, coapplication of rock powder with other fertilizers can increase the biomass production of crops (Anda et al., 2013; Leonardos et al., 1987; Theodoro et al., 2013).

An additional challenge of the application of rock products will be the assessment of the fate of weathering products, which might be transported eventually into river systems and alter geochemical baselines as evidenced by past land use changes in some large rivers (Hartmann et al., 2007; Raymond and Hamilton, 2018).

\section{Conclusions}

Our results illustrate the potential of enhanced weathering (EW) to act as a nutrient source for nutrient-demanding AR and BG. This is an important, yet often overlooked, aspect of $\mathrm{EW}$ besides $\mathrm{CO}_{2}$ sequestration. The investigated scenarios show that areas with undersupply of $\mathrm{P}$ exist, and a $\mathrm{C}$ stock reduction is expected to occur if $\mathrm{P}$ is the only limiting nutrient. Considering $\mathrm{N}$ and $\mathrm{P}$ deficiency together for a low geogenic $\mathrm{P}$ supply and high biomass $\mathrm{P}$ demand, the C-stock reduction will be up to $59 \%$ of the projected total global $\mathrm{C}$ sequestration potential of $224 \mathrm{Gt} \mathrm{C}$ from the $\mathrm{N}$-unlimited $\mathrm{AR}$ scenario. Potential P deficiencies were here based on the soil $\mathrm{P}$ availability and $\mathrm{P}$ demand scenarios, indicating that the inclusion of $\mathrm{P}$ cycles in AR models is necessary to accurately project the $\mathrm{C}$ sequestration of forests. Industrial fertilizers can be used to alleviate the $\mathrm{P}$ deficiency, but the extra input of ammonium along with it can undermine the carbon budget and acidify the soils. Furthermore, acidic soil conditions generally favor the sorption of orthophosphate onto $\mathrm{Fe}$ and Al-(hydro)oxides surfaces and clay minerals, essentially demobilizing P (Shen et al., 2011).

Besides the high chemical $\mathrm{P}$ content and relatively fast weathering rates, the equilibrated supply of $\mathrm{Ca}, \mathrm{K}$, and $\mathrm{Mg}$ puts the use of basalt powder one step ahead of other rocks as a potential alternative to industrial fertilizers. Regrowth of forests on abandoned agricultural land is a passive landscape restoration method (Bowen et al., 2007). In most of the cases soils become acidic on abandoned agricultural land in the long term (Hesterberg, 1993), which favors the leaching of nutrients (Haynes and Swift, 1986) and heavy metals (Hesterberg, 1993). As a consequence, the regrowth rate of forests might be limited in acidic soils. The use of basalt powder will keep a positive carbon budget; increase the soil $\mathrm{pH}$ (Anda et al., 2015, 2009), as basalt powder would act as a buffer maintaining soil $\mathrm{pH}$ under neutral to slight alkaline conditions; and close nutritional needs of $\mathrm{AR}$ and $\mathrm{BG}$, and rock powder can be used to reduce the risk of nitrate mobilization (Von Wilpert and Lukes, 2003). However, to be able to assess the global potential of the combination of land-based biomass NETs with EW, it is necessary to explore related physicochemical changes in soil influenced by varying EW deployment rates, based on already-available data, and then develop improved EW models. They should be tested with field-based approaches. For example, tracking added elements through the ecosystem's soil and plant reservoirs probably needs test sites that use advanced methods of nutrient balance and isotope studies, as recently developed (Uhlig et al., 2017; Uhlig and von Blanckenburg, 2019).

In addition to the use for replenishing soil nutrient content, our research suggests that deployment of rock powder on the topsoil can enhance plant-available water (PAW) for different upper limits. Apart from controlling the nutrient release rates, the texture of deployed rock powder would influence the impacts on soil hydrology together with the initial soil texture. In general, EW appears to have considerable potential for water retention management of topsoils. This is an important characteristic that has not been explored before, since under a future scenario of climate change, EW can potentially mitigate or alleviate drought effects to a certain extent within areas used for AR and BG plantation. Field and laboratory experiments are needed to quantify soil hydraulic changes under a natural and controlled environment. Besides that, investigation of potential changes in coupling EW with other terrestrial NETs such as biochar is necessary, since biochar and EW can increase the amount of soil organic matter, a variable also responsible for increasing the water retention of soils.

We show that EW can be an important part of the solution to the problem of nutrient limitation that AR and $B G$ might suffer from. Specifically, its potential for hydrological management of soils was shown, and it could be used in areas where seasonality and droughts might affect the biomass growth. The use of enhanced weathering for hydrological management coupled to land-based NETs is worth investigating. Global management of carbon pools will need a fullecosystem understanding, addressing nutrient fluxes and related soil mineralogy changes, soil hydrology, impacts on soil microorganisms, and responses of plants to the diverse array of soil types and climates. Applied ecosystem engineering is likely to be a future nexus discipline which needs to link local ecosystem processes with a global perspective on carbon pools within a universal effort to manage the carbon cycle.

Data availability. Data used for estimating initial soil hydraulic properties can be downloaded at https://data.isric.org/geonetwork/ srv/api/records/d9eca770-29a4-4d95-bf93-f32e1ab419c3 (Batjes, 2005). 
Data and scripts used from the Kracher (2017) AR model are archived by the Max Planck Institute for Meteorology and can be obtained by contacting publications@mpimet.mpg.de.

Data used for the estimation of nutrient export for bioenergy grass are available upon request to wagner.o.garcia@gmail.com.

The hardwood and softwood tree chemistry database can be downloaded at https://www.fs.usda.gov/treesearch/pubs/9464 (Pardo et al., 2005); additionally, the processed data are given as an Excel table in the Supplement.

The global leaf database can be downloaded at https://daac.ornl. gov/VEGETATION/guides/Leaf_carbon_nutrients.html (Vergutz et al., 2012).

The Global Gridded Soil Phosphorus Distribution Maps at a $0.5^{\circ}$ resolution can be downloaded at http://daac.ornl.gov/cgi-bin/ dsviewer.pl?ds_id=1223 (Yang et al., 2014a).

The used observation-based estimates of $\mathrm{P}$ release are available upon request to the original author (Hartmann et al., 2014).

The used global atmospheric $\mathrm{P}$ deposition data are available upon request to the original author (Wang et al., 2017).

Supplement. The supplement related to this article is available online at: https://doi.org/10.5194/bg-17-2107-2020-supplement.

Author contributions. This article was conceived by the joint work of all the authors, who participated in the discussions and writing, led by WdOG. The study was designed by WdOG, JH, and TA. WdOG compiled all the data used and conducted the calculations. KK and AP supplied the MAgPIE model simulations and the stoichiometric ratios used for bioenergy grass. LRB contributed to handling the JSBACH model outputs, and DG contributed to the methodology used to obtain the P-stock-based demand for AR.

Competing interests. The authors declare that they have no conflict of interest.

Acknowledgements. This study was funded by the German Research Foundation (Deutsche Forschungsgemeinschaft - DFG) priority program DFG SPP 1689 - Climate Engineering: Risks, Challenges, Opportunities? - and specifically the CEMICS2 project DFG-project HA4472/10-2. In addition this work was supported by the DFG under Germany's Excellence Strategy - EXC 2037 Climate, Climatic Change, and Society - project no. 390683824, and contributes to the Center for Earth System Research and Sustainability (CEN), University of Hamburg. Daniel Goll is funded by the IMBALANCE-P project of the European Research Council (ERC2013-SyG-610028). We are grateful for the constructive comments and suggestions from the reviewers and editor.

Financial support. This study was funded by the German Research Foundation priority program DFG SPP 1689 - Climate Engineering: Risks, Challenges, Opportunities? - and specifically the CEMICS2 project - DFG-project HA4472/10-2.
Review statement. This paper was edited by Alexey V. Eliseev and reviewed by Daniel Ibarra and one anonymous referee.

\section{References}

14688-1:2002: 14688-1:2002: Geotechnical investigation and testing-Identification and classification of soil-Part 1: Identification and description, International Organization for Standardization, Geneva, 2002.

Achat, D. L., Augusto, L., Gallet-Budynek, A., and Loustau, D.: Future challenges in coupled $\mathrm{C}-\mathrm{N}-\mathrm{P}$ cycle models for terrestrial ecosystems under global change: a review, Biogeochemistry, 131, 173-202, https://doi.org/10.1007/s10533-016-0274-9, 2016.

Amann, T. and Hartmann, J.: Ideas and perspectives: Synergies from co-deployment of negative emission technologies, Biogeosciences, 16, 2949-2960, https://doi.org/10.5194/bg-16-29492019, 2019.

Amiotte Suchet, P., Probst, J. L., and Ludwig, W.: Worldwide distribution of continental rock lithology: Implications for the atmospheric/soil $\mathrm{CO}_{2}$ uptake by continental weathering and alkalinity river transport to the oceans, Global Biogeochem. Cy., 17, 1038, 2003.

Anda, M., Shamshuddin, J., Fauziah, C. I., and Omar, S. R. S.: Dissolution of Ground Basalt and Its Effect on Oxisol Chemical Properties and Cocoa Growth, Soil Sci., 174, 264-271, https://doi.org/10.1097/SS.0b013e3181a56928, 2009.

Anda, M., Shamshuddin, J., and Fauziah, C. I.: Increasing negative charge and nutrient contents of a highly weathered soil using basalt and rice husk to promote cocoa growth under field conditions, Soil Till. Res., 132, 1-11, https://doi.org/10.1016/j.still.2013.04.005, 2013.

Anda, M., Shamshuddin, J., and Fauziah, C. I.: Improving chemical properties of a highly weathered soil using finely ground basalt rocks, Catena, 124, 147-161, https://doi.org/10.1016/j.catena.2014.09.012, 2015.

Appelo, C. A. J. and Postma, D.: Geochemistry, Groundwater and Pollution, Second Edition, CRC Press, 2005.

Aslyng, H.: Klima, jord og planter, Kulturteknik I, 5. Den. kgl Veter.- og Landbohosk, 368 pp., Kopenhavn, 1976.

Augusto, L., Achat, D. L., Jonard, M., Vidal, D., and Ringeval, B.: Soil parent material-A major driver of plant nutrient limitations in terrestrial ecosystems, Glob. Chang Biol., 23, 38083824, https://doi.org/10.1111/gcb.13691, 2017.

Batjes, N.: ISRIC-WISE global data set of derived soil properties on a 0.5 by 0.5 degree grid (version 3.0), ISRIC - World Soil Information, available at: https://data.isric.org/geonetwork/srv/api/ records/d9eca770-29a4-4d95-bf93-f32e1ab419c3 (last access: 16 April 2020), 2005.

Bear, J.: Dynamics of fluids in porous media, American Elsevier, New York, 1972.

Beech, E., Rivers, M., Oldfield, S., and Smith, P.: GlobalTreeSearch: The first complete global database of tree species and country distributions, J. Sustain. Forest., 36, 454-489, 2017.

Beerling, D. J., Leake, J. R., Long, S. P., Scholes, J. D., Ton, J., Nelson, P. N., Bird, M., Kantzas, E., Taylor, L. L., Sarkar, B., Kelland, M., DeLucia, E., Kantola, I., Müller, C., Rau, G., and Hansen, J.: Farming with crops and rocks to address 
global climate, food and soil security, Nat. Plants, 4, 138-147, https://doi.org/10.1038/s41477-018-0108-y, 2018.

Beringer, T., Lucht, W., and Schaphoff, S.: Bioenergy production potential of global biomass plantations under environmental and agricultural constraints, GCB Bioenergy, 3, 299-312, 2011.

Berner, A. R., Lasaga, A. C., and Garrels, R. M.: The carbonatesilicate geochemical cycle and its effect on atmospheric carbon dioxide over the past 100 million years, Am. J. Sci., 283, 641683, 1983.

Beyer, W.: Zur bestimmung der wasserdurchlässigkeit von kiesen und sanden aus der kornverteilungskurve, WWT, 14, 165-168, 1964.

Bissonnais, Y. L. and Singer, M. J.: Crusting, Runoff, and Erosion Response to Soil Water Content and Successive Rainfalls, Soil Sci. Soc. Am. J., 56, 1898-1903, https://doi.org/10.2136/sssaj1992.03615995005600060042x, 1992.

Bodirsky, B. L., Popp, A., Weindl, I., Dietrich, J. P., Rolinski, S., Scheiffele, L., Schmitz, C., and Lotze-Campen, $\mathrm{H} .: \mathrm{N}_{2} \mathrm{O}$ emissions from the global agricultural nitrogen cycle - current state and future scenarios, Biogeosciences, 9, 4169-4197, https://doi.org/10.5194/bg-9-4169-2012, 2012.

Bondeau, A., Smith, P. C., Zaehle, S., Schaphoff, S., Lucht, W., Cramer, W., Gerten, D., LOTZE-CAMPEN, H., Müller, C., and Reichstein, M.: Modelling the role of agriculture for the 20th century global terrestrial carbon balance, Glob. Change Biol., 13, 679-706, 2007.

Bonsch, M., Humpenöder, F., Popp, A., Bodirsky, B., Dietrich, J. P., Rolinski, S., Biewald, A., Lotze-Campen, H., Weindl, I., Gerten, D., and Stevanovic, M.: Trade-offs between land and water requirements for large-scale bioenergy production, GCB Bioenergy, 8, 11-24, https://doi.org/10.1111/gcbb.12226, 2016.

Börker, J., Hartmann, J., Romero-Mujalli, G., and Li, G.: Aging of basalt volcanic systems and decreasing $\mathrm{CO}_{2}$ consumption by weathering, Earth Surf. Dynam., 7, 191-197, https://doi.org/10.5194/esurf-7-191-2019, 2019.

Bowen, M. E., McAlpine, C. A., House, A. P. N., and Smith, G. C.: Regrowth forests on abandoned agricultural land: A review of their habitat values for recovering forest fauna, Biol. Conserv., 140, 273-296, https://doi.org/10.1016/j.biocon.2007.08.012, 2007.

Boysen, L. R., Lucht, W., and Gerten, D.: Trade-offs for food production, nature conservation and climate limit the terrestrial carbon dioxide removal potential, Glob. Change Biol., 23, 43034317, https://doi.org/10.1111/gcb.13745, 2017a.

Boysen, L. R., Lucht, W., Gerten, D., Heck, V., Lenton, T. M., and Schellnhuber, H. J.: The limits to global-warming mitigation by terrestrial carbon removal, Earth's Future, 5, 463-474, https://doi.org/10.1002/2016EF000469, 2017b.

Cadoux, S., Riche, A. B., Yates, N. E., and Machet, J.-M.: Nutrient requirements of Miscanthus x giganteus: Conclusions from a review of published studies, Biomass Bioenerg., 38, 14-22, https://doi.org/10.1016/j.biombioe.2011.01.015, 2012.

Calabrese, S., Porporato, A., and Parolari, A. J.: Hydrologic transport of dissolved inorganic carbon and its control on chemical weathering, J. Geophys. Res.-Earth, 122, 2016-2032, 2017.

Carrier III, W. D.: Goodbye, hazen; hello, kozeny-carman, J. Geotech. Geoenviron., 129, 1054-1056, 2003.
Christman, Z. J. and Rogan, J.: Error Propagation in Raster Data Integration, Photogramm. Eng. Rem. S., 78, 617-624, 2012.

Ciceri, D., de Oliveira, M., Stokes, R. M., Skorina, T., and Allanore, A.: Characterization of potassium agrominerals: Correlations between petrographic features, comminution and leaching of ultrapotassic syenites, Miner. Eng., 102, 42-57, https://doi.org/10.1016/j.mineng.2016.11.016, 2017.

Clarkson, D. T. and Hanson, J. B.: The Mineral Nutrition of Higher Plants, Annu. Rev. Plant Physiol., 31, 239-298, https://doi.org/10.1146/annurev.pp.31.060180.001323, 1980.

Cornelissen, S., Koper, M., and Deng, Y. Y.: The role of bioenergy in a fully sustainable global energy system, Biomass Bioenerg., 41, 21-33, https://doi.org/10.1016/j.biombioe.2011.12.049, 2012.

Creutzig, F.: Economic and ecological views on climate change mitigation with bioenergy and negative emissions, GCB Bioenergy, 8, 4-10, https://doi.org/10.1111/gcbb.12235, 2016.

Crowley, K. F., McNeil, B. E., Lovett, G. M., Canham, C. D., Driscoll, C. T., Rustad, L. E., Denny, E., Hallett, R. A., Arthur, M. A., Boggs, J. L., Goodale, C. L., Kahl, J. S., McNulty, S. G., Ollinger, S. V., Pardo, L. H., Schaberg, P. G., Stoddard, J. L., Weand, M. P., and Weathers, K. C.: Do Nutrient Limitation Patterns Shift from Nitrogen Toward Phosphorus with Increasing Nitrogen Deposition Across the Northeastern United States?, Ecosystems, 15, 940-957, https://doi.org/10.1007/s10021-012-9550-2, 2012.

Dietrich, J. P., Schmitz, C., Müller, C., Fader, M., Lotze-Campen, H., and Popp, A.: Measuring agricultural land-use intensity-A global analysis using a model-assisted approach, Ecol. Modell., 232, 109-118, 2012.

Dietrich, J. P., Schmitz, C., Lotze-Campen, H., Popp, A., and Müller, C.: Forecasting technological change in agriculture-an endogenous implementation in a global land use model, Technol. Forecast. Soc., 81, 236-249, 2014.

Dietrich, J. P., Bodirsky, B. L., Weindl, I., Humpenöder, F., Stevanovic, M., Kreidenweis, U., Wang, X., Karstens, K., Mishra, A., Klein, D., Ambrósio, G., Araujo, E., Biewald, A., Lotze-Campen, H., and Popp, A.: MAgPIE - An Open Source land-use modeling framework - Version 4.0, https://doi.org/10.5281/zenodo.1418752, 2018.

Dietzen, C., Harrison, R., and Michelsen-Correa, S.: Effectiveness of enhanced mineral weathering as a carbon sequestration tool and alternative to agricultural lime: An incubation experiment, Int. J. Greenh. Gas Con., 74, 251-258, 2018.

Doetterl, S., Berhe, A. A., Arnold, C., Bodé, S., Fiener, P., Finke, P., Fuchslueger, L., Griepentrog, M., Harden, J. W., Nadeu, E., Schnecker, J., Six, J., Trumbore, S., Van Oost, K., Vogel, C., and Boeckx, P.: Links among warming, carbon and microbial dynamics mediated by soil mineral weathering, Nat. Geosci., 11, 589593, https://doi.org/10.1038/s41561-018-0168-7, 2018.

Du, E., Terrer, C., Pellegrini, A. F. A., Ahlström, A., van Lissa, C. J., Zhao, X., Xia, N., Wu, X., and Jackson, R. B.: Global patterns of terrestrial nitrogen and phosphorus limitation, Nat. Geosci., 13, 221-226, https://doi.org/10.1038/s41561-019-0530-4, 2020.

Edwards, D. P., Lim, F., James, R. H., Pearce, C. R., Scholes, J., Freckleton, R. P., and Beerling, D. J.: Climate change mitigation: potential benefits and pitfalls of enhanced rock weathering in tropical agriculture, Biol. Lett.-UK, 13, 20160715 , https://doi.org/10.1098/rsbl.2016.0715, 2017. 
Elser, J. J., Bracken, M. E. S., Cleland, E. E., Gruner, D. S., Harpole, W. S., Hillebrand, H., Ngai, J. T., Seabloom, E. W., Shurin, J. B., and Smith, J. E.: Global analysis of nitrogen and phosphorus limitation of primary producers in freshwater, marine and terrestrial ecosystems, Ecol. Lett., 10, 1135-1142, https://doi.org/10.1111/j.1461-0248.2007.01113.x, 2007.

Fageria, N. K. and Baligar, V. C.: Chapter 7 Ameliorating Soil Acidity of Tropical Oxisols by Liming For Sustainable Crop Production, in: Advances in Agronomy, Academic Press, 345-399, 2008.

Fertilizer Technology Research Centre: Technical Bulletin: Fertilizer and Soil Acidity, in: The University of Adelaide, edited by: McLaughlin, M., available at: http://sciences.adelaide.edu.au/fertiliser/system/files/media/ documents/2020-01/factsheet-fertilizers-and-soil-acidity.pdf, (last access: 24 September 2019), 2016.

Fischer, G., Shah, M., van Velthuizen, H., and Nachtergaele, F. O.: Global agro-ecological assessment for agriculture in the 21st century, Internation Institute for Applied Systems Analysis (IIASA), Laxenburg, Austria, 2001.

Fishkis, O., Ingwersen, J., Lamers, M., Denysenko, D., and Streck, T.: Phytolith transport in soil: A field study using fluorescent labelling, Geoderma, 157, 27-36, https://doi.org/10.1016/j.geoderma.2010.03.012, 2010.

Fuss, S., Lamb, W. F., Callaghan, M. W., Hilaire, J., Creutzig, F., Amann, T., Beringer, T., de Oliveira Garcia, W., Hartmann, J., Khanna, T., Luderer, G., Nemet, G. F., Rogelj, J., Smith, P., Vicente, J. L. V., Wilcox, J., del Mar Zamora Dominguez, M., and Minx, J. C.: Negative emissions-Part 2: Costs, potentials and side effects, Environ. Res. Lett., 13, 063002, https://doi.org/10.1088/1748-9326/aabf9f, 2018.

Gaillardet, J., Dupré, B., Louvat, P., and Allegre, C.: Global silicate weathering and $\mathrm{CO}_{2}$ consumption rates deduced from the chemistry of large rivers, Chem. Geol., 159, 3-30, 1999.

Gaiser, T., Graef, F. C., and Carvalho, J.: Water retention characteristics of soils with contrasting clay mineral composition in semi-arid tropical regions, Soil Res., 38, 523-536, https://doi.org/10.1071/SR99001, 2000.

Garcia, D. O. W., Amann, T., and Hartmann, J.: Increasing biomass demand enlarges negative forest nutrient budget areas in wood export regions, Sci. Rep.-UK, 8, 5280, https://doi.org/10.1038/s41598-018-22728-5, 2018.

Gijsman, A. J., Jagtap, S. S., and Jones, J. W.: Wading through a swamp of complete confusion: how to choose a method for estimating soil water retention parameters for crop models, Eur. J. Agron., 18, 77-0106, https://doi.org/10.1016/S11610301(02)00098-9, 2002.

Goddéris, Y., François, L. M., Probst, A., Schott, J., Moncoulon, D., Labat, D., and Viville, D.: Modelling weathering processes at the catchment scale: The WITCH numerical model, Geochim. Cosmochim. Ac., 70, 1128-1147, https://doi.org/10.1016/j.gca.2005.11.018, 2006.

Goll, D. S., Brovkin, V., Parida, B. R., Reick, C. H., Kattge, J., Reich, P. B., van Bodegom, P. M., and Niinemets, Ü.: Nutrient limitation reduces land carbon uptake in simulations with a model of combined carbon, nitrogen and phosphorus cycling, Biogeosciences, 9, 3547-3569, https://doi.org/10.5194/bg-9-35472012, 2012.
Goll, D. S., Moosdorf, N., Hartmann, J., and Brovkin, V.: Climate-driven changes in chemical weathering and associated phosphorus release since 1850: Implications for the land carbon balance, Geophys. Res. Lett., 41, 3553-3558, https://doi.org/10.1002/2014GL059471, 2014.

Goll, D. S., Winkler, A. J., Raddatz, T., Dong, N., Prentice, I. C., Ciais, P., and Brovkin, V.: Carbon-nitrogen interactions in idealized simulations with JSBACH (version 3.10), Geosci. Model Dev., 10, 2009-2030, https://doi.org/10.5194/gmd-102009-2017, 2017.

Goll, D. S., Joetzjer, E., Huang, M., and Ciais, P.: Low Phosphorus Availability Decreases Susceptibility of Tropical Primary Productivity to Droughts, Geophys. Res. Lett., 45, 8231-8240, https://doi.org/10.1029/2018g1077736, 2018.

Goswami, S., Fisk, M. C., Vadeboncoeur, M. A., Garrison-Johnston, M., Yanai, R. D., and Fahey, T. J.: Phosphorus limitation of aboveground production in northern hardwood forests, Ecology, 99, 438-449, https://doi.org/10.1002/ecy.2100, 2018.

Grathwohl, P.: On equilibration of pore water in column leaching tests, Waste Manage., 34, 908-918, https://doi.org/10.1016/j.wasman.2014.02.012, 2014.

Hartmann, J. and Kempe, S.: What is the maximum potential for $\mathrm{CO}_{2}$ sequestration by "stimulated" weathering on the global scale?, Naturwissenschaften, 95, 1159-1164, https://doi.org/10.1007/s00114-008-0434-4, 2008.

Hartmann, J., Jansen, N., Kempe, S., and Dürr, H. H.: Geochemistry of the river Rhine and the upper Danube: Recent trends and lithological influence on baselines, Journal of Environmental Science for Sustainable Society, 1, 39-46, 2007.

Hartmann, J., Jansen, N., Dürr, H. H., Kempe, S., and Köhler, P.: Global $\mathrm{CO}_{2}$-consumption by chemical weathering: What is the contribution of highly active weathering regions?, Global Planet. Change, 69, 185-194, 2009.

Hartmann, J., West, A. J., Renforth, P., Köhler, P., De La Rocha, C. L., Wolf-Gladrow, D. A., Durr, H. H., and Scheffran, J.: Enhanced chemical weathering as a geoengineering strategy to reduce atmospheric carbon dioxide, supply nutrients, and mitigate ocean acidification, Rev. Geophys., 51, 113-149, https://doi.org/10.1002/rog.20004, 2013.

Hartmann, J., Moosdorf, N., Lauerwald, R., Hinderer, M., and West, A. J.: Global chemical weathering and associated P-release - The role of lithology, temperature and soil properties, Chem. Geol., 363, 145-163, https://doi.org/10.1016/j.chemgeo.2013.10.025, 2014.

Haynes, R. J. and Swift, R. S.: Effects of soil acidification and subsequent leaching on levels of extractable nutrients in a soil, Plant Soil, 95, 327-336, https://doi.org/10.1007/bf02374613, 1986.

He, Y., Zhu, Y., Smith, S., and Smith, F.: Interactions between soil moisture content and phosphorus supply in spring wheat plants grown in pot culture, J. Plant Nutr., 25, 913-925, https://doi.org/10.1081/PLN-120002969, 2002.

He, Y., Shen, Q., Kong, H., Xiong, Y., and Wang, X.: Effect of soil moisture content and phosphorus application on phosphorus nutrition of rice cultivated in different water regime systems, J. Plant Nutr., 27, 2259-2272, 2005.

Herbert, D. A. and Fownes, J. H.: Phosphorus limitation of forest leaf area and net primary production on a highly weathered soil, Biogeochemistry, 29, 223-235, https://doi.org/10.1007/bf02186049, 1995. 
Hesterberg, D.: Effects of stopping liming on abandoned agricultural land, Land Degrad. Dev., 4, 257-267, https://doi.org/10.1002/ldr.3400040409, 1993.

Holtan, H., Kamp-Nielsen, L., and Stuanes, A. O.: Phosphorus in Soil, Water and Sediment: An Overview, in: Phosphorus in Freshwater Ecosystems, edited by: Persson, G. and Jansson, M., Developments in Hydrobiology, Springer, Dordrecht, 19-34, 1988.

Hopkins, W. G. and Hüner, N. P. A.: Introduction to plant physiology, Ed. 4, John Wiley and Sons, 2008.

Humpenöder, F., Popp, A., Dietrich, J. P., Klein, D., Lotze-Campen, H., Bonsch, M., Bodirsky, B. L., Weindl, I., Stevanovic, M., and Müller, C.: Investigating afforestation and bioenergy CCS as climate change mitigation strategies, Environ. Res. Lett., 9, 064029, https://doi.org/10.1088/1748-9326/9/6/064029, 2014.

Hurtt, G. C., Chini, L. P., Frolking, S., Betts, R. A., Feddema, J., Fischer, G., Fisk, J. P., Hibbard, K., Houghton, R. A., Janetos, A., Jones, C. D., Kindermann, G., Kinoshita, T., Klein Goldewijk, K., Riahi, K., Shevliakova, E., Smith, S., Stehfest, E., Thomson, A., Thornton, P., van Vuuren, D. P., and Wang, Y. P.: Harmonization of land-use scenarios for the period 1500-2100: 600 years of global gridded annual land-use transitions, wood harvest, and resulting secondary lands, Climatic Change, 109, 117, https://doi.org/10.1007/s10584-011-0153-2, 2011.

IGBP-DIS: A program for creating global soil-property databases, IGBP Global Soils Data Task, France, 1998.

Irvine, T. and Baragar, W.: A guide to the chemical classification of the common volcanic rocks, Can. J. Earth Sci., 8, 523-548, 1971.

John, W.: An introduction to igneous and metamorphic petrology, Prentice Hall, Upper Saddle River, NJ, 347 pp., 2001.

Johnson, A. H., Frizano, J., and Vann, D. R.: Biogeochemical implications of labile phosphorus in forest soils determined by the Hedley fractionation procedure, Oecologia, 135, 487-499, https://doi.org/10.1007/s00442-002-1164-5, 2003.

Jonard, M., Legout, A., Nicolas, M., Dambrine, E., Nys, C., Ulrich, E., Perre, R., and Ponette, Q.: Deterioration of Norway spruce vitality despite a sharp decline in acid deposition: a longterm integrated perspective, Glob. Change Biol., 18, 711-725, https://doi.org/10.1111/j.1365-2486.2011.02550.x, 2012.

Jonard, M., Furst, A., Verstraeten, A., Thimonier, A., Timmermann, V., Potocic, N., Waldner, P., Benham, S., Hansen, K., Merila, P., Ponette, Q., de la Cruz, A. C., Roskams, P., Nicolas, M., Croise, L., Ingerslev, M., Matteucci, G., Decinti, B., Bascietto, M., and Rautio, P.: Tree mineral nutrition is deteriorating in Europe, Glob. Chang Biol., 21, 418-430, https://doi.org/10.1111/gcb.12657, 2015.

Kang, Y., Khan, S., and Ma, X.: Climate change impacts on crop yield, crop water productivity and food security - A review, Prog. Nat. Sci., 19, 1665-1674, https://doi.org/10.1016/j.pnsc.2009.08.001, 2009.

Kantola, I. B., Masters, M. D., Beerling, D. J., Long, S. P., and DeLucia, E. H.: Potential of global croplands and bioenergy crops for climate change mitigation through deployment for enhanced weathering, Biol. Lett., 13, 20160714, https://doi.org/10.1098/rsbl.2016.0714, 2017.

Kempe, S.: Carbon in the rock cycle, The global carbon cycle, 380, 343-375, 1979.

Knust, C., Schua, K., and Feger, K.-H.: Estimation of Nutrient Exports Resulting from Thinning and Intensive Biomass Extrac- tion in Medium-Aged Spruce and Pine Stands in Saxony, Northeast Germany, Forests, 7, 302, https://doi.org/10.3390/f7120302, 2016.

Kracher, D.: Nitrogen-Related Constraints of Carbon Uptake by Large-Scale Forest Expansion: Simulation Study for Climate Change and Management Scenarios, Earth's Future, 5, 11021118, https://doi.org/10.1002/2017EF000622, 2017.

Kvakić, M., Pellerin, S., Ciais, P., Achat, D. L., Augusto, L., Denoroy, P., Gerber, J. S., Goll, D., Mollier, A., Mueller, N. D., Wang, X., and Ringeval, B.: Quantifying the Limitation to World Cereal Production Due To Soil Phosphorus Status, Global Biogeochem. Cy., 32, 143-157, https://doi.org/10.1002/2017gb005754, 2018.

La Scala, N., Bolonhezi, D., and Pereira, G. T.: Short-term soil $\mathrm{CO}_{2}$ emission after conventional and reduced tillage of a no-till sugar cane area in southern Brazil, Soil Till. Res., 91, 244-248, https://doi.org/10.1016/j.still.2005.11.012, 2006.

Landeweert, R., Hoffland, E., Finlay, R. D., Kuyper, T. W., and van Breemen, N.: Linking plants to rocks: ectomycorrhizal fungi mobilize nutrients from minerals, Trends Ecol. Evol., 16, 248-254, https://doi.org/10.1016/S0169-5347(01)02122-X, 2001.

Lenton, T. M.: The potential for land-based biological $\mathrm{CO}_{2}$ removal to lower future atmospheric $\mathrm{CO}_{2}$ concentration, Carbon Manag., 1, 145-160, 2010.

Lenton, T. M.: The global potential for carbon dioxide removal, Geoengineering of the Climate System, edited by: Harrison, R. M. and Hester, R. E., Cambridge, The Royal Society of Chemistry, London, 52-79, 2014.

Lenton, T. M. and Britton, C.: Enhanced carbonate and silicate weathering accelerates recovery from fossil fuel $\mathrm{CO}_{2}$ perturbations, Global Biogeochem. Cy., 20, GB3009, https://doi.org/10.1029/2005GB002678, 2006.

Leonardos, O. H., Fyfe, W. S., and Kronberg, B. I.: The use of ground rocks in laterite systems: An improvement to the use of conventional soluble fertilizers?, Chem. Geol., 60, 361-370, https://doi.org/10.1016/0009-2541(87)90143-4, 1987.

Liu, S., Han, C., Liu, J., and Li, H.: Hydrothermal decomposition of potassium feldspar under alkaline conditions, RSC Adv., 5, 93301-93309, 2015.

Lotze-Campen, H., Müller, C., Bondeau, A., Rost, S., Popp, A., and Lucht, W.: Global food demand, productivity growth, and the scarcity of land and water resources: a spatially explicit mathematical programming approach, Agr. Econ., 39, 325-338, 2008.

Ma, X., Ma, H., and Yang, J.: Sintering Preparation and Release Properties of $\mathrm{K}_{2} \mathrm{MgSi}_{3} \mathrm{O}_{8}$ Slow-Release Fertilizer Using Biotite Acid-Leaching Residues as Silicon Source, Ind. Eng. Chem. Res., 55, 10926-10931, 2016a.

Ma, X., Yang, J., Ma, H., and Liu, C.: Hydrothermal extraction of potassium from potassic quartz syenite and preparation of aluminum hydroxide, Int. J. Miner. Process., 147, 10-17, $2016 \mathrm{~b}$.

Madsen, H. B.: Distribution of spring barley roots in Danish soils, of different texture and under different climatic conditions, Plant Soil, 88, 31-43, https://doi.org/10.1007/bf02140664, 1985.

Menge, D. N. L., Hedin, L. O., and Pacala, S. W.: Nitrogen and Phosphorus Limitation over Long-Term Ecosystem Development in Terrestrial Ecosystems, PLoS ONE, 7, e42045, https://doi.org/10.1371/journal.pone.0042045, 2012.

Mersi, W. V., Kuhnert-Finkernagel, R., and Schinner, F.: The influence of rock powders on microbial activity of 
three forest soils, Z. Pflanz. Bodenkunde, 155, 29-33, https://doi.org/10.1002/jpln.19921550107, 1992.

Moon, S., Chamberlain, C. P., and Hilley, G. E.: New estimates of silicate weathering rates and their uncertainties in global rivers, Geochim. Cosmochim. Ac., 134, 257-274, https://doi.org/10.1016/j.gca.2014.02.033, 2014

Müller, C. and Robertson, R. D.: Projecting future crop productivity for global economic modeling, Agr. Econ., 45, 37-50, https://doi.org/10.1111/agec.12088, 2013.

Munkholm, L. J., Schjønning, P., and Sørensen, H.: Jordpakning og mekanisk løsning på grovsandet jord, Ministeriet for Fødevarer, Landbrug og Fiskeri, Viborg, 6 pp., 2003.

National Research Council: Climate Intervention: Carbon Dioxide Removal and Reliable Sequestration, The National Academies Press, Washington, DC, 154 pp., 2015.

Nkouathio, D. G., Wandji, P., Bardintzeff, J. M., Tematio, P., Kagou Dongmo, A., and Tchoua, F.: Utilisation des roches volcaniques pour la remineralisation des sols ferrallitiques des regions tropicales. Cas des pyroclastites basaltiques du graben de Tombel (Ligne volcanique du Cameroun), Bull. Soc. Vaudoise Sci. Nat., 14 pp., 2008.

Noordin, W., Zulkefly, S., Shamshuddin, J., and Hanafi, M.: Improving soil chemical properties and growth performance of $\mathrm{He}$ vea Brasiliensis through basalt application, International Proceedings of IRC 2017, 1, 308-323, 2017.

Nunes, J. M. G., Kautzmann, R. M., and Oliveira, C.: Evaluation of the natural fertilizing potential of basalt dust wastes from the mining district of Nova Prata (Brazil), J. Clean. Prod., 84, 649656, https://doi.org/10.1016/j.jclepro.2014.04.032, 2014.

Olness, A. and Archer, D.: Effect of organic carbon on available water in soil, Soil Sci., 170, 90-101, 2005.

Olsen, M.: Orienterende fors $\emptyset \mathrm{g}$ vedrørende jordes dybdebehandling, Hedeselskabets Forskningsvirksomhed, Viborg, 41 pp., 1958.

Oren, R., Ellsworth, D. S., Johnsen, K. H., Phillips, N., Ewers, B. E., Maier, C., Schafer, K. V., McCarthy, H., Hendrey, G., McNulty, S. G., and Katul, G. G.: Soil fertility limits carbon sequestration by forest ecosystems in $\mathrm{CO}_{2}$-enriched atmosphere, Nature, 411, 469-472, https://doi.org/10.1038/35078064, 2001.

Pardo, L. H., Robin-Abbott, M., Duarte, N., and Miller, E., K.: Tree Chemistry Database (Version 1.0), United States Department of Agriculture, NE-324. Newtown Square PA, Gen. Tech. Rep., 45, available at: https://www.fs.usda.gov/treesearch/pubs/9464 (last access: 14 April 2020), 2005.

Pontius, R.: Quantification error versus location error in comparison of categorical maps, Photogramm. Eng. Rem. S., 66, 540-540, 2000.

Popp, A., Lotze-Campen, H., and Bodirsky, B.: Food consumption, diet shifts and associated non- $\mathrm{CO}_{2}$ greenhouse gases from agricultural production, Global Environ. Chang., 20, 451-462, 2010.

Popp, A., Lotze-Campen, H., Leimbach, M., Knopf, B., Beringer, T., Bauer, N., and Bodirsky, B.: On sustainability of bioenergy production: Integrating co-emissions from agricultural intensification, Biomass Bioenerg., 35, 4770-4780, https://doi.org/10.1016/j.biombioe.2010.06.014, 2011.

Popp, A., Calvin, K., Fujimori, S., Havlik, P., Humpenöder, F., Stehfest, E., Bodirsky, B. L., Dietrich, J. P., Doelmann, J. C., Gusti, M., Hasegawa, T., Kyle, P., Obersteiner, M., Tabeau, A., Takahashi, K., Valin, H., Waldhoff, S., Weindl, I., Wise,
M., Kriegler, E., Lotze-Campen, H., Fricko, O., Riahi, K., and Vuuren, D. P. V.: Land-use futures in the shared socioeconomic pathways, Global Environ. Chang., 42, 331-345, https://doi.org/10.1016/j.gloenvcha.2016.10.002, 2017.

Porder, S. and Hilley, G. E.: Linking chronosequences with the rest of the world: predicting soil phosphorus content in denuding landscapes, Biogeochemistry, 102, 153-166, https://doi.org/10.1007/s10533-010-9428-3, 2011.

Porder, S. and Ramachandran, S.: The phosphorus concentration of common rocks-a potential driver of ecosystem P status, Plant Soil, 367, 41-55, 2013.

Raymond, P. A. and Hamilton, S. K.: Anthropogenic influences on riverine fluxes of dissolved inorganic carbon to the oceans, Limnology and Oceanography Letters, 3, 143-155, 2018.

Reick, C. H., Raddatz, T., Brovkin, V., and Gayler, V.: Representation of natural and anthropogenic land cover change in MPI-ESM, J. Adv. Model. Earth Sy., 5, 459-482, https://doi.org/10.1002/jame.20022, 2013.

Reicosky, D. C.: Tillage-induced $\mathrm{CO}_{2}$ emission from soil, Nutr. Cycl. Agroecosys., 49, 273-285, https://doi.org/10.1023/A:1009766510274, 1997.

Renforth, P.: The potential of enhanced weathering in the UK, Int. J. Greenh. Gas Con., 10, 229-243, https://doi.org/10.1016/j.ijggc.2012.06.011, 2012.

Renforth, P., von Strandmann, P. A. E. P., and Henderson, G. M.: The dissolution of olivine added to soil: Implications for enhanced weathering, Appl. Geochem., 61, 109-118, https://doi.org/10.1016/j.apgeochem.2015.05.016, 2015.

Ringeval, B., Kvakić, M., Augusto, L., Ciais, P., Goll, D., Mueller, N. D., Müller, C., Nesme, T., Vuichard, N., Wang, X., and Pellerin, S.: Insights on nitrogen and phosphorus co-limitation in global croplands from theoretical and modelling fertilization experiments, Biogeosciences Discuss., https://doi.org/10.5194/bg2019-298, 2019.

Rockström, J., Steffen, W., Noone, K., Persson, Å., Chapin Iii, F. S., Lambin, E. F., Lenton, T. M., Scheffer, M., Folke, C., Schellnhuber, H. J., Nykvist, B., de Wit, C. A., Hughes, T., van der Leeuw, S., Rodhe, H., Sörlin, S., Snyder, P. K., Costanza, R., Svedin, U., Falkenmark, M., Karlberg, L., Corell, R. W., Fabry, V. J., Hansen, J., Walker, B., Liverman, D., Richardson, K., Crutzen, P., and Foley, J. A.: A safe operating space for humanity, Nature, 461, 472-475, https://doi.org/10.1038/461472a, 2009.

Romero-Mujalli, G., Hartmann, J., Börker, J., Gaillardet, J., and Calmels, D.: Ecosystem controlled soil-rock $\mathrm{pCO}_{2}$ and carbonate weathering - Constraints by temperature and soil water content, Chem. Geol., 527, 118634, https://doi.org/10.1016/j.chemgeo.2018.01.030, 2018.

Rossato, L., Alvalá, R. C. D. S., Marengo, J. A., Zeri, M., Cunha, A. P. M. D. A., Pires, L. B. M., and Barbosa, H. A.: Impact of Soil Moisture on Crop Yields over Brazilian Semiarid, Front. Environ. Sci., 5, 73, https://doi.org/10.3389/fenvs.2017.00073, 2017.

Sadras, V. O. and Milroy, S. P.: Soil-water thresholds for the responses of leaf expansion and gas exchange: A review, Field Crop. Res., 47, 253-266, https://doi.org/10.1016/03784290(96)00014-7, 1996.

Sairam, R.: Physiology of waterlogging tolerance in plants, National Seminar on Sustainable Crop Productivity through Physiological Interventions, 24-26 November 2011, Matunga, Mumbai, 2011. 
Saxton, K., Rawls, W. J., Romberger, J., and Papendick, R.: Estimating generalized soil-water characteristics from texture 1, Soil Sci. Soc. Am. J., 50, 1031-1036, 1986.

Saxton, K. E. and Rawls, W. J.: Soil water characteristic estimates by texture and organic matter for hydrologic solutions, Soil Sci. Soc. Am. J., 70, 1569-1578, 2006.

Schaap, M. G., Leij, F. J., and van Genuchten, M. T.: rosetta: a computer program for estimating soil hydraulic parameters with hierarchical pedotransfer functions, J. Hydrol., 251, 163-176, https://doi.org/10.1016/S0022-1694(01)00466-8, 2001.

Schuiling, R. D. and Krijgsman, P.: Enhanced Weathering: An Effective and Cheap Tool to Sequester $\mathrm{CO}_{2}$, Climatic Change, 74, 349-354, https://doi.org/10.1007/s10584-005-3485-y, 2006.

Sharpley, A.: Phosphorus availability, CRC Press, Boca Raton Florida, D18-D37, 2000.

Shen, J., Yuan, L., Zhang, J., Li, H., Bai, Z., Chen, X., Zhang, W., and Zhang, F.: Phosphorus Dynamics: From Soil to Plant, Plant Physiol., 156, 997-1005, https://doi.org/10.1104/pp.111.175232, 2011.

Singh, B. and Schulze, D.: Soil minerals and plant nutrition, Nature Education Knowledge, 6, 1, 2015.

Smeets, E. M. W. and Faaij, A. P. C.: Bioenergy potentials from forestry in 2050, Climatic Change, 81, 353-390, https://doi.org/10.1007/s10584-006-9163-x, 2007.

Smith, P.: Agricultural greenhouse gas mitigation potential globally, in Europe and in the UK: what have we learnt in the last 20 years?, Glob. Change Biol., 18, 35-43, https://doi.org/10.1111/j.1365-2486.2011.02517.x, 2012.

Smith, P., Davis, S. J., Creutzig, F., Fuss, S., Minx, J., Gabrielle, B., Kato, E., Jackson, R. B., Cowie, A., Kriegler, E., van Vuuren, D. P., Rogelj, J., Ciais, P., Milne, J., Canadell, J. G., McCollum, D., Peters, G., Andrew, R., Krey, V., Shrestha, G., Friedlingstein, P., Gasser, T., Grübler, A., Heidug, W. K., Jonas, M., Jones, C. D., Kraxner, F., Littleton, E., Lowe, J., Moreira, J. R., Nakicenovic, N., Obersteiner, M., Patwardhan, A., Rogner, M., Rubin, E., Sharifi, A., Torvanger, A., Yamagata, Y., Edmonds, J., and Yongsung, C.: Biophysical and economic limits to negative $\mathrm{CO}_{2}$ emissions, Nature Climate Change, 6, 42-50, https://doi.org/10.1038/nclimate2870, 2015.

Smith, P., Davis, S. J., Creutzig, F., Fuss, S., Minx, J., Gabrielle, B., Kato, E., Jackson, R. B., Cowie, A., Kriegler, E., van Vuuren, D. P., Rogelj, J., Ciais, P., Milne, J., Canadell, J. G., McCollum, D., Peters, G., Andrew, R., Krey, V., Shrestha, G., Friedlingstein, P., Gasser, T., Grubler, A., Heidug, W. K., Jonas, M., Jones, C. D., Kraxner, F., Littleton, E., Lowe, J., Moreira, J. R., Nakicenovic, N., Obersteiner, M., Patwardhan, A., Rogner, M., Rubin, E., Sharifi, A., Torvanger, A., Yamagata, Y., Edmonds, J., and Yongsung, C.: Biophysical and economic limits to negative $\mathrm{CO}_{2}$ emissions, Nat. Clim. Change, 6, 42-50, https://doi.org/10.1038/nclimate2870, 2016.

Smith, W. K., Zhao, M., and Running, S. W.: Global Bioenergy Capacity as Constrained by Observed Biospheric Productivity Rates, BioScience, 62, 911-922, https://doi.org/10.1525/bio.2012.62.10.11, 2012.

Sonntag, S., Pongratz, J., Reick, C. H., and Schmidt, H.: Reforestation in a high- $\mathrm{CO}_{2}$ world-Higher mitigation potential than expected, lower adaptation potential than hoped for, Geophys. Res. Lett., 43, 6546-6553, https://doi.org/10.1002/2016gl068824, 2016.
Stefánsson, A., Giìslason, S. R., and Arnórsson, S.: Dissolution of primary minerals in natural waters: II. Mineral saturation state, Chem. Geol., 172, 251-276, 2001.

Straaten, P. V.: Agrogeology: the use of rocks for crops, 631.4 S894, Ed. Enviroquest Ltd, 440 pp., 2007.

Strefler, J., Amann, T., Bauer, N., Kriegler, E., and Hartmann, J.: Potential and costs of Carbon Dioxide Removal by Enhanced Weathering of rocks, Environ. Res. Lett., 13, 034010, https://doi.org/10.1088/1748-9326/aaa9c4, 2018.

Sun, Y., Peng, S., Goll, D. S., Ciais, P., Guenet, B., Guimberteau, M., Hinsinger, P., Janssens, I. A., Peñuelas, J., Piao, S., Poulter, B., Violette, A., Yang, X., Yin, Y., and Zeng, H.: Diagnosing phosphorus limitations in natural terrestrial ecosystems in carbon cycle models, Earth's Future, 5, 730-749, https://doi.org/10.1002/2016ef000472, 2017.

Tanner, E. V. J., Vitousek, P. M., and Cuevas, E.: Experimental investigation of nutrient limitation of forest growth on wet tropical mountains, Ecology, 79, 10-22, 1998.

Taylor, L. L., Leake, J. R., Quirk, J., Hardy, K., Banwart, S. A., and Beerling, D. J.: Biological weathering and the long-term carbon cycle: integrating mycorrhizal evolution and function into the current paradigm, Geobiology, 7, 171-191, https://doi.org/10.1111/j.1472-4669.2009.00194.x, 2009.

Taylor, L. L., Quirk, J., Thorley, R. M. S., Kharecha, P. A., Hansen, J., Ridgwell, A., Lomas, M. R., Banwart, S. A., and Beerling, D. J.: Enhanced weathering strategies for stabilizing climate and averting ocean acidification, Nat. Clim. Change, 6, 402-406, https://doi.org/10.1038/nclimate2882, 2015.

Theodoro, S. H., de Souza Martins, E., Fernandes, M. M., and de Carvalho, A. M. X.: II Congresso Brasileiro de Rochagem, Poços de Caldas - MG, 2013.

Thomson, A. M., Calvin, K. V., Smith, S. J., Kyle, G. P., Volke, A., Patel, P., Delgado-Arias, S., Bond-Lamberty, B., Wise, M. A., Clarke, L. E., and Edmonds, J. A.: RCP4.5: a pathway for stabilization of radiative forcing by 2100 , Climatic Change, 109 , 77-94, https://doi.org/10.1007/s10584-011-0151-4, 2011.

Tokimatsu, K., Yasuoka, R., and Nishio, M.: Global zero emissions scenarios: The role of biomass energy with carbon capture and storage by forested land use, Appl. Energ., 185, 1899-1906, https://doi.org/10.1016/j.apenergy.2015.11.077, 2017.

Uhlig, D. and von Blanckenburg, F.: How Slow Rock Weathering Balances Nutrient Loss During Fast Forest Floor Turnover in Montane, Temperate Forest Ecosystems, Front. Earth Sci., 7, 159, https://doi.org/10.3389/feart.2019.00159, 2019.

Uhlig, D., Schuessler, J. A., Bouchez, J., Dixon, J. L., and von Blanckenburg, F.: Quantifying nutrient uptake as driver of rock weathering in forest ecosystems by magnesium stable isotopes, Biogeosciences, 14, 3111-3128, https://doi.org/10.5194/bg-143111-2017, 2017.

Vergutz, L., Manzoni, S., Porporato, A., Novais, R. F., and Jackson, R. B.: A Global Database of Carbon and Nutrient Concentrations of Green and Senesced Leaves, ORNL Distributed Active Archive Center, available at: https://daac.ornl. gov/VEGETATION/guides/Leaf_carbon_nutrients.html (last access: 14 April 2020), 2012.

Vienken, T. and Dietrich, P.: Field evaluation of methods for determining hydraulic conductivity from grain size data, J. Hydrol., 400, 58-71, 2011. 
Vitousek, P. M., Aber, J. D., Howarth, R. W., Likens, G. E., Matson, P. A., Schindler, D. W., Schlesinger, W. H., and Tilman, D. G.: Human alteration of the global nitrogen cycle: sources and consequences, Ecol. Appl., 7, 737-750, 1997.

Vitousek, P. M., Porder, S., Houlton, B. Z., and Chadwick, O. A.: Terrestrial phosphorus limitation: mechanisms, implications, and nitrogen-phosphorus interactions, Ecol. Appl., 20, 5-15, https://doi.org/10.1890/08-0127.1, 2010.

von Liebig, J. F. and Playfair, L. P. B.: Chemistry in its application to agriculture and physiology, JM Campbell, 1843.

Von Wilpert, K. and Lukes, M.: Ecochemical effects of phonolite rock powder, dolomite and potassium sulfate in a spruce stand on an acidified glacial loam, Nutr. Cycl. Agroecosys., 65, 115127, 2003.

Waldbauer, J. R. and Chamberlain, C. P.: Influence of uplift, weathering, and base cation supply on past and future $\mathrm{CO}_{2}$ levels, in: A history of atmospheric $\mathrm{CO}_{2}$ and its effects on Plants, Animals, and Ecosystems, Springer, 166-184, 2005.

Walker, J. C., Hays, P., and Kasting, J. F.: A negative feedback mechanism for the long-term stabilization of Earth's surface temperature, J. Geophys. Res.-Oceans, 86, 9776-9782, 1981.

Wang, R., Goll, D., Balkanski, Y., Hauglustaine, D., Boucher, O., Ciais, P., Janssens, I., Penuelas, J., Guenet, B., Sardans, J., Bopp, L., Vuichard, N., Zhou, F., Li, B., Piao, S., Peng, S., Huang, Y., and Tao, S.: Global forest carbon uptake due to nitrogen and phosphorus deposition from 1850 to 2100 , Glob. Change Biol., 23, 4854-4872, https://doi.org/10.1111/gcb.13766, 2017.

Wang, Y. P., Law, R. M., and Pak, B.: A global model of carbon, nitrogen and phosphorus cycles for the terrestrial biosphere, Biogeosciences, 7, 2261-2282, https://doi.org/10.5194/bg-7-22612010, 2010.

Whitfield, C. J. and Reid, C.: Predicting surface area of coarsetextured soils: Implications for weathering rates, Can. J. Soil Sci., 93, 621-630, 2013.

Wösten, J. H. M., Pachepsky, Y. A., and Rawls, W. J.: Pedotransfer functions: bridging the gap between available basic soil data and missing soil hydraulic characteristics, J. Hydrol., 251, 123-150, https://doi.org/10.1016/S0022-1694(01)00464-4, 2001.
Wright, S. J., Yavitt, J. B., Wurzburger, N., Turner, B. L., Tanner, E. V., Sayer, E. J., Santiago, L. S., Kaspari, M., Hedin, L. O., and Harms, K. E.: Potassium, phosphorus, or nitrogen limit root allocation, tree growth, or litter production in a lowland tropical forest, Ecology, 92, 1616-1625, 2011.

Yang, X., Post, W. M., Thornton, P. E., and Jain, A. K.: Global Gridded Soil Phosphorus Distribution Maps at 0.5-degree Resolution, ORNL Distributed Active Archive Center, available at: http://daac.ornl.gov/cgi-bin/dsviewer.pl?ds_id=1223 (last access: 14 April 2020), 2014a.

Yang, X., Thornton, P. E., Ricciuto, D. M., and Post, W. M.: The role of phosphorus dynamics in tropical forests - a modeling study using CLM-CNP, Biogeosciences, 11, 1667-1681, https://doi.org/10.5194/bg-11-1667-2014, 2014b.

Yasunari, T.: The Uplift of the Himalaya-Tibetan Plateau and $\mathrm{Hu}-$ man Evolution: An Overview on the Connection Among the Tectonics, Eco-Climate System and Human Evolution During the Neogene Through the Quaternary Period, in: Himalayan Weather and Climate and their Impact on the Environment, edited by: Dimri, A. P., Bookhagen, B., Stoffel, M., and Yasunari, T., Springer International Publishing, Cham, 281-305, 2020.

Yousefpour, R., Nabel, J. E. M. S., and Pongratz, J.: Simulating growth-based harvest adaptive to future climate change, Biogeosciences, 16, 241-254, https://doi.org/10.5194/bg-16-241-2019, 2019.

Zaehle, S. and Dalmonech, D.: Carbon-nitrogen interactions on land at global scales: current understanding in modelling climate biosphere feedbacks, Curr. Opin. Env. Sust., 3, 311-320, 2011. 